UNIVERSIDADE ESTADUAL PAULISTA

FACULDADE DE MEDICINA VETERINÁRIA E ZOOTECNIA

CAMPUS DE BOTUCATU

\title{
EFEITO DA TEMPERATURA SOBRE O DESEMPENHO E A QUALIDADE DOS OVOS DE CODORNAS JAPONESAS
}

FRANCINE VERCESE

Dissertação apresentada ao Programa de Pós-graduação em Zootecnia como parte das exigências para obtenção do título de Mestre.

BOTUCATU - SP

Janeiro - 2010 
UNIVERSIDADE ESTADUAL PAULISTA

FACULDADE DE MEDICINA VETERINÁRIA E ZOOTECNIA

CAMPUS DE BOTUCATU

\section{EFEITO DA TEMPERATURA SOBRE O DESEMPENHO E A QUALIDADE DOS OVOS DE CODORNAS JAPONESAS}

FRANCINE VERCESE

Zootecnista

ORIENTADOR: Prof. Dr. Edivaldo Antônio Garcia CO-ORIENTADOR: Prof. Dr. José Roberto Sartori

Dissertação apresentada ao Programa de Pós-graduação em Zootecnia como parte das exigências para obtenção do título de Mestre.

BOTUCATU - SP

Janeiro - 2010 
FICHA CATALOGRÁFICA ELABORADA PELA SEÇÃO TÉCNICA DE AQUISIÇÃO E TRATAMENTO DA INFORMAÇÃO - SERVIÇO TÉCNICO DE BIBLIOTECA E DOCUMENTAÇÃO - UNESP - FCA - LAGEADO - BOTUCATU (SP)

Vercese, Francine, 1982-

V481e Efeito da temperatura sobre o desempenho e a qualidade dos ovos de codornas japonesas / Francine Vercese. Botucatu : [s.n.], 2010.

viii, $59 \mathrm{f}$. : foto color., tabs.

Dissertação (Mestrado) - Universidade Estadual Paulista, Faculdade de Medicina Veterinária e Zootecnia, Botucatu, 2010

Orientador: Edivaldo Antonio Garcia

Co-orientador: José Roberto Sartori

Inclui bibliografia.

1. Estresse por calor. 2. Ovos - Produção. 3. Desempenho. 4. Codornas japonesas. I. Garcia, Edivaldo Antonio. II. Sartori, José Roberto. III. Universidade Estadual Paulista "Júlio de Mesquita Filho" (Campus de Botucatu). Faculdade de Medicina Veterinária e Zootecnia. IV. Título. 
"A beleza não está na partida nem na chegada, mas na travessia" (Guimarães Rosa)

"Para cultivar a sabedoria, é preciso força interior. Sem crescimento interno, é difícil conquistar a autoconfiança e a coragem necessárias. Sem elas, nossa vida se complica. 0 impossível torna-se possível com a força de vontade."

(Dalai Lama) 


\title{
DEDICATÓRIA
}

\author{
"Aos meus pais, Alberto Garavazzo Vercese \\ e Sônia Regina Scarabel Vercese pelo amor, \\ confiança e apoio incondicional que forneceram a mim \\ energia e a vontade necessárias para alcançar mais esta etapa. \\ À memória de meu avô, Alberto Scarabel, \\ exemplo de luta nesta jornada de nossas vidas. \\ Aos meus irmãos Melina Vercese e Natan Vercese, \\ pela convivência e amizade. \\ A todos os familiares e amigos que, diretamente \\ ou indiretamente, puderam conviver cada minuto \\ desta jornada. \\ Foram anos de saudades, privações, dedicação, \\ trabalho, acertos e erros, mas principalmente \\ de bons momentos... \\ Com amor e carinho, \\ DEDICO."
}




\section{AGRADECIMENTOS}

Acima de tudo, agradeço a Deus pela dádiva da vida e por, em muitos momentos aflitivos, proporcionar-me paz e serenidade para enfrentar os obstáculos e superar os desafios.

A Faculdade de Medicina Veterinária e Zootecnia - Unesp, Campus de Botucatu e ao Programa de Pós-Graduação em Zootecnia pela oportunidade de realização do curso.

A Fundação de Amparo à Pesquisa do Estado de São Paulo (FAPESP) pela concessão da bolsa de estudos.

Ao meu orientador, Prof. Dr. Edivaldo Antônio Garcia, pela orientação, ensinamentos, contribuição e incentivo para obstruir as palavras, "difícil, impossível e complicado" do meu vocabulário e tornar possível a execução desta jornada, contribuindo em minha formação, tanto profissional como pessoal.

Ao meu co-orientador, Prof. Dr. José Roberto Sartori, pela amizade, apoio e importante contribuição neste trabalho.

Aos professores do Departamento de Produção Animal, em especial ao Prof. Dr. Alcides de Amorim Ramos, pela amizade e colaboração na realização das análises estatísticas.

Aos professores da Pós-Graduação da FMVZ pela orientação, amizade e valiosos ensinamentos ao longo do curso, em especial Margarida Maria Barros e Luiz Edivaldo Pezzato.

Aos professores Raphael Lúcio Andreatti Filho, Antônio Carlos de Laurentiz e Sílvia Maria Alves Gomes pelas correções e sugestões que muito contribuíram com este trabalho.

Aos funcionários da Seção de Pós-Graduação, Seila Cristina Cassineli Vieira, Danilo Juarez Teodoro Dias e Carlos Pazini Jr. pela paciência, consideração e auxílios prestados. 
Aos funcionários e estagiários do Laboratório de Bromatologia, em especial Renato Monteiro e Gisele Setznael pela colaboração na condução das análises laboratoriais.

Aos funcionários da FMVZ - Unesp/Botucatu, em especial, José Luis Barbosa, Solange Aparecida Ferreira de Souza, Paulo Inácio Primo, Paulo Matias, Paulo Sérgio Luiz, Luiz Carlos Fioravante, José Ramos Martins, Edivaldo Gomes Torquato, Sebastião Francisco da Silva Filho, Valdomiro de Souza David, Celso Paulo Martin, Adenilson Lima Lucas, Cláudio Gouveia, Antônio Carlos Godoy, Obedias Florêncio de Oliveira, João Faustino Fogaça, Paulo Sérgio dos Santos, Gilson de Campos, Renato Agostinho de Campos, Rodrigo Martin, José Antônio Franco, Ana Pires, Irene Francisca de Arruda, Magali de Arruda, Valdice Rodrigues e Silene V. Mamede, pelos auxílios prestados, convivência e amizade.

Aos colegas do Curso de Pós-Graduação, em especial Ana Beatriz Garcia Faitarone, Andréa de Britto Molino, Daniella Aparecida Berto, Kléber Pelícia, Anderson Pontes Silva e Érika Salgado Politi Braga Saldanha pelo apoio, convívio e momentos de descontração.

Aos amigos "ilhenses", Cecília Silva de Castro, Gabriella de Mello, Juliana Sversut de Alexandre, Milena Penteado Chaguri, Fabiana Alves de Almeida e Fábio Henrique Takahashi pela amizade sincera, apoio e incentivo durante a execução desta tarefa.

Aos meus amigos e "companheiros de batalha", Elisane Lenita Milbradt e João Guilherme Ferreira pelo apoio, auxílio na execução de meu experimento e por me ajudarem a superar momentos difíceis desta jornada.

Aos estagiários do setor de Avicultura, em especial Thiago Peregrino de Brito pela ajuda incansável e pelas palavras de fé que me ajudaram a superar as barreiras e os desafios impostos durante a execução desta etapa de minha vida.

E a todos que, através de um simples sorriso, olhar, gesto, cumprimento contribuíram para a realização deste trabalho, 


\section{SUMÁRIO}

Página

CAPÍTULO 1................................................................................................... 1

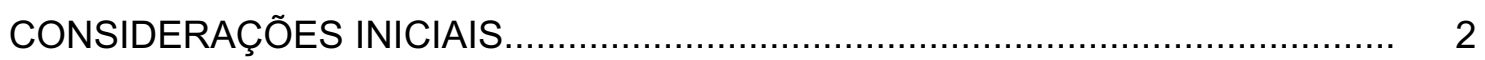

Revisão Bibliográfica........................................................................... 3

Ambiência na avicultura de postura............................................................. 3

Aspectos fisiológicos.......................................................................... 6

Diagnóstico climático brasileiro................................................................ 9

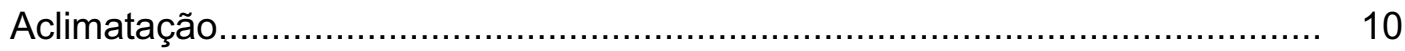

Efeitos do estresse por calor sobre os parâmetros produtivos....................... 12

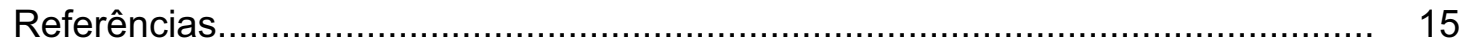

CAPÍTULO 2

EFEITO DO ESTRESSE CONTÍNUO PELO CALOR SOBRE O DESEMPENHO E A QUALIDADE DE OVOS DE CODORNAS JAPONESAS ................................. 22

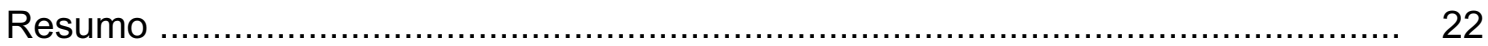

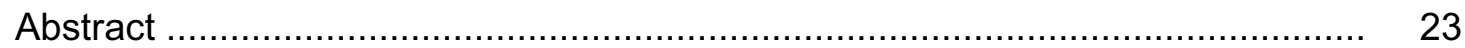

Introdução ...................................................................................... 24

Material e métodos.................................................................................. 26

Resultados e Discussão.......................................................................... $\quad 30$

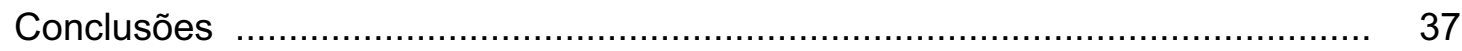

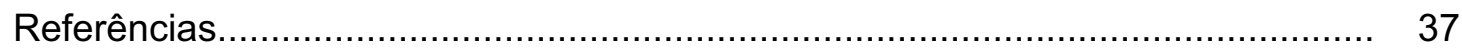

CAPÍTULO 3........................................................................................................ 41

DESEMPENHO E QUALIDADE DE OVOS DE CODORNAS JAPONESAS SOB

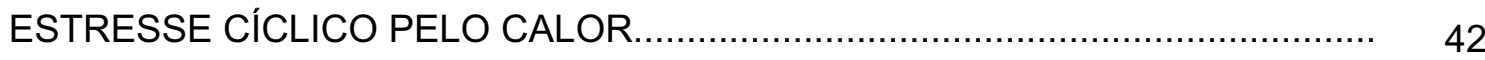

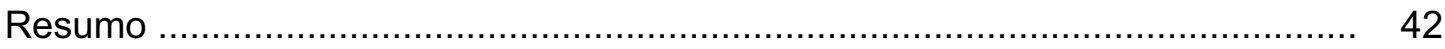

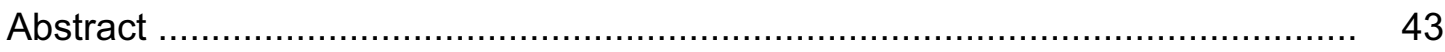

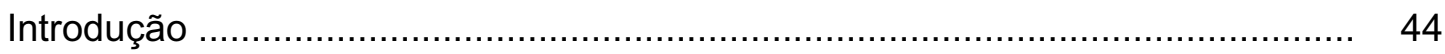

Material e métodos.................................................................................... 45

Resultados e Discussão........................................................................... 48

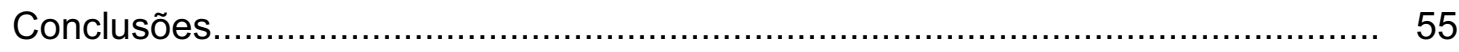

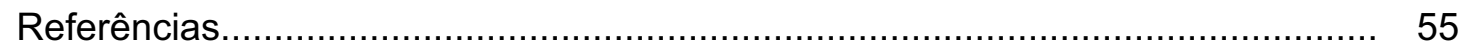

Implicações...................................................................................... 59 
ÍNDICE DE TABELAS

Página

Capitulo 2. .21

Tabela 1. Médias de temperaturas máxima ( $T M A X)$ e mínima ( $T$ MIN) e umidade relativa do ar máxima (UR MAX) e mínima (UR MIN) nas câmaras climáticas. .30

Tabela 2. Consumo de ração (CR), Percentagem de postura (POST), percentagem de ovos viáveis (OVI), peso dos ovos (PO), massa de ovos (MO), conversão alimentar por dúzia $(\mathrm{CA} / \mathrm{dz})$ e por quilograma $(\mathrm{CA} / \mathrm{kg})$ de ovos produzidos de codornas japonesas submetidas a estresse por calor......

Tabela 3. Gravidade específica (GE), resistência de casca à quebra (RES), espessura de casca (ESP), percentagem de casca (CASC), índice gema (IG), percentagem de gema (GEM), percentagem de albúmen (ALB) e unidade Haugh (UH) de ovos de codornas japonesas submetidas a estresse por calor.

Tabela 4. Percentagem de sólidos do albúmen e da gema para a temperatura termoneutra $\left(21^{\circ} \mathrm{C}\right)$ e para as temperaturas testes $(24,27,30,33$ e $\left.36^{\circ} \mathrm{C}\right)$ .37

Capitulo 3. .41

Tabela 1. Médias de temperaturas máxima ( $T$ MAX) e mínima ( $T$ MIN) e umidade relativa do ar máxima (UR MAX) e mínima (UR MIN) nas câmaras climáticas.

Tabela 2. Consumo de ração (CR), Percentagem de postura (POST), percentagem de ovos viáveis (OVI), peso dos ovos (PO), massa de ovos (MO), conversão alimentar por dúzia $(\mathrm{CA} / \mathrm{dz})$ e por quilograma $(\mathrm{CA} / \mathrm{kg})$ de ovos produzidos de codornas japonesas submetidas a estresse cíclico por calor...

Tabela 3. Gravidade específica (GE), resistência de casca à quebra (RES), espessura de casca (ESP), percentagem de casca (CASC), índice gema (IG), percentagem de gema (GEM), percentagem de albúmen (ALB) e unidade Haugh (UH) de ovos de codornas japonesas submetidas a estresse cíclico por calor. 
Tabela 4. Percentagem de sólidos do albúmen e da gema para a temperatura termoneutra $\left(21^{\circ} \mathrm{C}\right)$ e para as temperaturas testes $(24,27,30,33 \mathrm{e}$ $\left.36^{\circ} \mathrm{C}\right)$ .55 
ÍNDICE DE FIGURAS

\section{CAPÍTULO 2}

Figuras 1A e 1B. Disposição da bateria na câmara bioclimática e detalhe da gaiola. 
CAPÍTULO 1 


\section{CONSIDERAÇÕES INICIAIS}

O Brasil possui grande potencial de crescimento para o agronegócio, principalmente devido aos progressos tecnológicos nas áreas de genética, nutrição, manejo e sanidade, que transformam a produção animal e de derivados em grande empreendimento econômico provedor de proteína animal, na forma de carne e ovos para a população.

A criação de codornas vem se destacando ao longo dos anos, com cada vez mais adeptos. Fatores como pequena exigência de espaço, baixo consumo de ração, pequeno intervalo de geração, maturidade precoce e alta taxa de crescimento inicial favorecem a caracterização da codorna como uma ave excelente, tanto para utilização em instituições de pesquisa como para produção de carne ou ovos em diferentes regiões.

Durante muitos anos sua exploração comercial foi basicamente restrita ao mercado atacadista e aos supermercados. A partir da década de 90 houve grande acréscimo na produção em decorrência da alteração nas características dos mercados atacadistas e varejistas, uma vez que os ovos comercializados preferencialmente in natura passaram também a ser processados em indústrias beneficiadoras, através dos ovos descascados ou em conserva, muito utilizados em churrascarias, restaurantes, bares e lanchonetes.

Segundo dados registrados pelo IBGE (2009), durante os anos de 2006 a 2007 houve uma variação na produção de $25,8 \%$, saltando de 123,706 para 131,045 milhões de dúzias de ovos de codornas. Em 2008, foram produzidas 157,781 milhões de dúzias com aumento de 20,4\% relativo ao ano de 2007 .

Dados registrados por Oliveira (2007) permitem observar que houve aumento significativo da produção de ovos de codornas sem grandes variações no tamanho do rebanho. $\mathrm{O}$ aumento da produtividade pode ser atribuído ao uso de tecnologias na atividade e ao aproveitamento da infra-estrutura e experiência da avicultura de postura na produção e comercialização.

As exportações brasileiras de ovos de galinha cresceram $111 \%$ de janeiro a outubro de 2008 , quando comparadas a igual período de 2007 , passando de US\$ 33 milhões para US\$ 69 milhões. De janeiro a outubro de 2008, as exportações brasileiras para países árabes cresceram $423 \%$ em relação ao mesmo período de 2007, saltando de US\$ 6,14 milhões para US\$ 32,14 milhões. Em volume, passaram de 16,5 milhões de dúzias, nos primeiros dez meses de 2007, para 46,7 milhões de 
dúzias de janeiro a outubro de 2008 (AVICULTURA INDUSTRIAL, 2008). Este aumento na exportação de ovos de galinha pode representar um avanço para coturnicultura brasileira devido à abertura de novas fronteiras mercadológicas.

Atualmente, a região sudeste destaca-se como maior produtora nacional de ovos de galinha, além de demonstrar grande crescimento na produção de ovos de codornas. São Paulo, Espírito Santo e Minas Gerais destacam-se como maiores estados produtores de ovos de codorna (IBGE, 2009).

Para manter a posição obtida em escala de produção, além da conquista de novos mercados, torna-se necessário conhecer os efeitos deletérios de temperaturas elevadas, prevalecentes na maioria das regiões brasileiras durante grande parte do ano, sobre o desempenho e qualidade dos ovos de codornas japonesas para que se possam adotar medidas corretivas a fim de minimizar estes efeitos sobre a produção e ainda promover maior bem-estar às aves.

\section{REVISÃO BIBLIOGRÁFICA}

Ambiência na avicultura de postura

Face à importância do ambiente em que as aves são criadas, os aspectos sociais, principalmente baseados no comportamento das aves, até então relegados a um plano secundário, tornam-se cada vez mais evidentes na exploração avícola moderna (MANNING, 1972). Assim, os estudos envolvendo fatores relacionados ao bem-estar animal principalmente quando associado às respostas fisiológicas tem alcançado, nos últimos anos, destaque especial.

Em países desenvolvidos, campanhas movidas por diferentes segmentos e a pressão de um número crescente de organizações não-governamentais sensibilizaram a opinião pública para esse aspecto, o que originou progressos legislativos consideráveis. Questões relacionadas ao bem-estar dos animais em condições intensivas, além da utilização dos recursos naturais, assumirão papel cada vez mais importante no contexto da produção mundial (ALVES et al., 2007). Este fato é fortalecido por grandes consumidores e redes varejistas, em especial a União Européia, que impõem métodos de produção, utilizando aves não criadas em gaiolas, ou em número inferior ao usado no momento, insistindo ainda em não utilizar a prática da debicagem e não indução a muda forçada.

O conceito de ambiente é amplo, uma vez que inclui todas as condições que afetam o desenvolvimento dos animais (ROLLER e STOMBAUGH, 1976). O ambiente 
na produção animal engloba o ambiente térmico (temperatura, umidade, velocidade do vento e outros), o ambiente acústico (ruídos), o ambiente aéreo (gases e poeiras) e o ambiente social (hierarquia do grupo e tratador). $\mathrm{O}$ ambiente físico pode abranger os elementos meteorológicos que afetam os mecanismos de transferência de calor, a regulação e o balanço térmico entre o animal e o meio, exercendo forte influência sobre o bem-estar e desempenho do animal (ASHARAE, 1985).

De acordo com North e Bell (1990), vários são os fatores envolvidos na eficiência da produção de um lote de poedeiras. Além da linhagem, a idade ao início da postura, o peso corporal e sua uniformidade, nutrição, sanidade e o manejo aplicado estão amplamente relacionados. A manutenção e o controle desses fatores dependem das condições do ambiente físico ao qual a ave está submetida. Segundo Marsden e Morris (1975), idade e temperatura ambiente estão entre os fatores mais importantes que afetam o desempenho das aves poedeiras. Dessa forma, as características meteorológicas do ambiente de criação são fatores fundamentais no desempenho produtivo.

As variáveis do clima regem os níveis necessários de controle artificial do ambiente no sistema de manejo e, consequentemente, no custo econômico do manejo microambiental. A umidade relativa em conjunto com a temperatura ambiental possuem papel importante na dissipação de calor pelos animais. Em condições de temperaturas ambientais muito elevadas, associadas aos altos valores de umidade relativa do ar há redução no desempenho produtivo. No interior das instalações zootécnicas, a umidade relativa pode variar em função da temperatura do ambiente de criação, do fluxo de vapor oriundo dos animais, das fezes e/ou da cama e do sistema de ventilação (BAIÃO, 1995; ZANOLLA, 1998).

O distanciamento da temperatura ambiente dos valores próximos à região termoneutra dos animais desequilibra o mecanismo termodinâmico que as aves possuem para se protegerem de extremos climáticos, levando ao desperdício de energia, em seu conceito mais amplo (ABREU e ABREU, 2003).

Existem evidências científicas suficientes para concluir que o calor e o frio são importantes agentes de modificação do comportamento, da resposta e da susceptibilidade às doenças. Considerando que o potencial genético, os avanços na formulação de dietas, equipamentos e rotinas de manejo progrediram muito nos últimos anos, o controle de ambiente passou a ter importância cada vez maior na maximização da eficiência produtiva e da competitividade econômica do setor (PERDOMO, 1998). 
Os efeitos de temperaturas elevadas sobre a qualidade dos ovos em galinhas poedeiras são relatados há bastante tempo (BENNION e WARREN, 1933). Porém, poucos estudos tem sido realizados para avaliar tais efeitos sobre os parâmetros de qualidade em ovos de codornas. Portanto, um conhecimento mais aprofundado sobre os diversos elementos do ambiente físico que influenciam diretamente as aves poedeiras exerce grande importância na tentativa de modificar o impacto do ambiente sobre a produção de ovos (SILVA, 2001).

As aves são classificadas como animais homeotermos e apresentam capacidade de manter a temperatura interna constante. De acordo com os princípios da termodinâmica, isso significa que estes animais estão em troca contínua com o ambiente. Segundo Silva (2001), este processo é eficiente somente quando a temperatura ambiental estiver dentro dos limites da termoneutralidade.

A definição de conforto térmico segundo Smith (1964) é aquela em que a resposta animal ao ambiente é positiva e a demanda ambiental é conciliada com a produção basal, acrescida da produção de calor equivalente à atividade normal e do incremento calórico da alimentação. A zona de conforto é variável de acordo com diversos fatores como fase de criação, manejo e ambiente.

A zona de termoneutralidade está relacionada com o ambiente térmico ideal, no qual a amplitude é bem estreita. Nesta, o animal alcança seu potencial máximo e a temperatura corporal é mantida com mínima utilização de mecanismos termorreguladores (SILVA et al.,1994).

De acordo com Von Borell (1995), estresse é um termo geral que implica uma ameaça à qual determinado organismo precisa se ajustar. Segundo Fraser et al. (1975), diz-se que um animal está em estado de estresse quando são necessários ajustes em sua fisiologia ou em seu comportamento, para adequar-se aos aspectos adversos decorrentes do manejo ou do ambiente no qual se encontra. Mench (2002) caracteriza a presença ou ausência de estresse como um potencial indicador do bemestar animal.

Dependendo da magnitude e da duração do estresse térmico sofrido pelos animais pode ocorrer desde decréscimos no ganho de peso, até a prostração e morte (MITCHELL, 1987). Comparando-se a temperatura interna das aves com a dos mamíferos, observa-se que além de ser mais alta, é mais variável, podendo, quando adultas, variar de 41 a $42^{\circ} \mathrm{C}$. Tais variações ocorrem de acordo com a idade, peso corporal, sexo, atividade física, consumo de alimentos e ambiente térmico do galpão. 
Segundo Alvarez e Delgado (2000), o horário crítico para ocorrência do estresse térmico das aves está entre $10 \mathrm{~h} 00$ e 16h00, levando em consideração que entre $01 \mathrm{~h} 00$ e $07 \mathrm{~h} 00$ horas praticamente não ocorrem valores de temperaturas maiores que $26^{\circ} \mathrm{C}$ e que entre $19 \mathrm{~h} 00$ e $22 \mathrm{~h} 00$ não ocorrem valores de temperaturas maiores que $28^{\circ} \mathrm{C}$, ambas toleráveis para galinhas poedeiras.

A falta de bem-estar e conforto térmico em poedeiras provoca uma série de consequências que estão intimamente ligadas à queda no consumo de alimentos, menor taxa de crescimento, alteração da conversão alimentar, queda na produção de ovos e maior incidência de ovos com casca mole.

\section{Aspectos fisiológicos}

A fisiologia descreve o funcionamento do organismo do animal. Embora o corpo normalmente tente manter um estado de equilíbrio (homeostase), ele possui mecanismos que permitem a quebra deste equilíbrio como resposta a estímulos variados. Fatores de estresse como o clima, mudança de ambiente, ruído, elevada densidade de animais, etc., levam à liberação de hormônios que podem identificar o nível de estresse do animal. Quando sob condições de estresse, as aves respondem com alterações fisiológicas que podem estar relacionadas às mudanças no eixo do estresse. Os resultados são: elevada frequência cardíaca, aumento no corticosterona plasmático e níveis de catecolaminas, hipertrofia e atrofia da adrenal, imunossupressão, mudanças nos hormônios reprodutivos e do crescimento e mudanças neuroquímicas (FREEMAN, 1988).

As trocas de calor entre animal e ambiente apresentam dois fluxos os quais podem ser denominados de calor sensível ou não evaporativo que envolve os processos de condução, radiação e convecção e calor latente ou evaporativo (BAETA, 1998).

No calor sensível ou não evaporativo, a condução é mecanismo de ganho ou perda de calor através da transmissão de energia térmica durante a colisão entre moléculas e pode ser observado no animal em contato com outras substâncias como ar, água, piso das instalações, etc. A radiação é o processo no qual a superfície de todos os objetos emitem calor na forma de ondas eletromagnéticas. Nas aves, o ganho por calor é significativo se considerarmos a insolação e a energia térmica proveniente de telhados e instalações. A convecção é a troca de calor através de correntes aéreas e depende da temperatura do ar, da superfície corporal e da 
velocidade do ar ao redor do corpo. A ventilação favorece as perdas de calor entre aves e o ambiente.

A perda de calor sensível nas aves é afetada pelas penas, que funcionam como um isolante térmico, em contrapartida a presença de apêndices pode favorecer a perda do calor. Crista e barbela podem alcançar até $50 \mathrm{~cm}^{2}$ e representam $7 \%$ da área total do corpo da ave (FREEMAN e COGBURN, 1983).

O calor latente ou evaporativo envolve processos de evaporação e condensação (BAETA, 1998). A evaporação é o mecanismo de troca de calor através da mudança do estado da água de líquido para gasoso, sendo este processo um carreador de calor para fora do corpo do animal. A perda de calor em aves ocorre principalmente através do trato respiratório. Como a evaporação é dependente da pressão de vapor d'água, a medida em que aumenta a umidade do ar, a perda por evaporação diminui. É importante o controle da umidade do ar dentro das instalações; em ambiente de temperatura e umidade do ar elevadas, as perdas de calor latente são prejudicadas e a condição de estresse é acentuada. A condensação é um mecanismo sem importância entre o animal e o ambiente.

As aves dispõem de um centro termorregulador, localizado no hipotálamo, capaz de controlar a temperatura corporal através de mecanismos fisiológicos e respostas comportamentais, mediante a produção e liberação de calor, determinando assim a manutenção da temperatura corporal normal (MACARI et al., 1994).

A vasodilatação periférica é uma das respostas fisiológicas das aves, quando expostas ao calor, resultando em aumento na perda de calor não evaporativo. A ave consegue aumentar a área superficial, mantendo as asas afastadas do corpo, eriçando as penas e intensificando a circulação periférica na tentativa de aumentar a dissipação do calor. Outra forma de perda de calor não evaporativo ocorre com o aumento da produção de urina, se esta perda de água for compensada pelo maior consumo de água fria. Outra resposta ao estresse pelo calor é o aumento da concentração de glicose em resposta direta a maior secreção de adrenalina, noradrenalina e glicocorticóides (BORGES, 1999; BORGES, 2002).

As aves apresentam reduzida capacidade de troca térmica, na forma latente, com o ambiente e uma baixa profundidade respiratória. Devido a isto é necessário aumento da frequência respiratória para eliminação de calor e isto leva a um maior atrito entre músculos envolvidos na respiração, gerando mais calor ao corpo animal, Os animais entram em estado de ofegação com pequeno aumento da temperatura ambiente. Todavia, em condições de estresse térmico, esse mecanismo de ofegação 
nas aves é um dos meios mais eficientes de dissipação de calor (FREEMAN, 1988). Como consequência, há um aumento da movimentação do ar no sistema respiratório da ave, determinando a perda excessiva de dióxido de carbono do sangue para o ar via pulmões.

Segundo Linsley e Berger (1964), a frequência respiratória em frangos de corte se situa em torno 25 movimentos por minuto em ambiente de conforto térmico. Quando submetidas ao estresse por calor agudo, a frequência aumenta em torno de 250 movimentos por minuto. Em galinhas poedeiras, a frequência respiratória pode variar de 23 movimentos por minuto em temperatura ambiente a 273 movimentos por minuto em situações de temperaturas elevadas (KASSIM e SYKES, 1982).

A perda de $\mathrm{CO}_{2}$, devido a maior frequência respiratória, resulta na alcalose desregulando o balanço ácido-básico da ave. Embora a alcalose seja compensada pelos rins, condições prolongadas de temperaturas elevadas determinam a ocorrência de alcalose crônica (LINSLEY e BERGER,1964).

Furlan (1999) submetendo cinco linhagens comerciais de frangos de corte ao estresse por calor verificou que, independente da linhagem, as aves apresentaram redução no percentual de $\mathrm{CO}_{2}$ e aumento no $\mathrm{pH}$ sanguíneo com a elevação da temperatura.

As galinhas poedeiras também são afetadas por alterações no equilíbrio ácidobásico durante períodos de altas temperaturas, que desencadeiam um desequilíbrio eletrolítico e mineral, podendo resultar em ovos pequenos e de casca fina. Isto ocorre, principalmente, porque a alcalose reduz a concentração de cálcio livre no sangue e aumenta a proporção de cálcio ligado à proteína ou complexado com ácidos orgânicos. Assim, durante o estresse por calor há um aumento de pH sanguíneo, devido a perda de dióxido de carbono, acompanhado de diminuição no cálcio difusível (FURLAN, 2009).

Embora possa ser importante para a compensação de alcalose, a descarga de ácidos orgânicos no sangue é prejudicial à manutenção do nível de cálcio ionizado, pois os ácidos orgânicos (lático, pirúvico) possuem capacidade de complexar cálcio, o que restringe ainda mais a disponibilidade do mesmo para a formação da casca do ovo (ODOM et al., 1986).

Pesquisas realizadas por Lesson e Summers (1991) indicam que, em condições de alcalose respiratória, há redução na calcificação dos ovos e dos ossos o que compromete o desempenho de matrizes, contribuindo para o aumento da incidência de problemas de pernas nas aves e produção de ovos com casca fina. 
Outro método de troca de calor é o aumento no consumo de água. Costa (1980) observou que em temperaturas moderadas $\left(20^{\circ} \mathrm{C}\right)$, a ingestão de água de uma poedeira é de aproximadamente 1,9 a 2 vezes maior que a quantidade de alimento ingerido. Em temperaturas elevadas esta ingestão de água pode aumentar de 4 a 5 vezes.

A temperatura da água interfere no consumo de ração, diminuindo-o quando a temperatura da água aumenta. Resultados de pesquisas indicam que a resposta desencadeada no nervo lingual da ave inicia-se quando a temperatura da água atinge a faixa de $24^{\circ} \mathrm{C}$ (MACARI, 1995).

Diversos autores verificaram que a temperatura da água está diretamente relacionada com a temperatura do interior do galpão (BARROT e PRINGLE, 1949; JOINER e HUSTON 1957; SARTORI, 1996). Segundo Macari et al. (1994), a temperatura ideal da água é de $24^{\circ} \mathrm{C}$ e, acima deste ponto, as trocas térmicas entre água e ave são reduzidas.

Diagnóstico climático brasileiro

O território brasileiro apresenta com uma característica climática muito diversificada, indo do super úmido quente da Amazônia, passando pelo úmido quente e subsequente, semi-úmido quente até o semi-árido brando, mediano, forte e muito forte do Nordeste (PERDOMO, 1998).

Na região Sul, destaca-se a precipitação uniforme (1200 a 2000 mm) do ritmo estacional e predominância do clima mesotérmico temperado. Os verões são quentes, com média das máximas em torno de $30-32^{\circ} \mathrm{C}$ em áreas de altitudes baixas e $24^{\circ} \mathrm{C}$ no planalto. No inverno, a média das máximas no vale é de 20 a $24^{\circ} \mathrm{C}$ e 16 a $20^{\circ} \mathrm{C}$ no planalto. Há uma transição entre os climas quentes de latitude baixas e os climas mesotérmicos de latitude média na região Sudeste. Temperaturas médias de $20^{\circ} \mathrm{C}$ entre São Paulo e Paraná e de $24^{\circ} \mathrm{C}$ ao norte de Minas Gerais. As temperaturas máximas absolutas são inferiores a $35^{\circ} \mathrm{C}$ nas áreas altas, mas superam os $40^{\circ} \mathrm{C}$ nos vales. A precipitação ultrapassa os $1500 \mathrm{~mm}$ e o período seco, com variação de um a seis meses de duração, ocorre no inverno (PERDOMO, 1998).

A região Centro-Oeste se caracteriza por clima muito diversificado devido a continentalidade, extensão latitudinal, relevo e circulação atmosférica e apresenta temperaturas elevadas com médias variando de $22^{\circ} \mathrm{C}$ ao norte, 20 a $22^{\circ} \mathrm{C}$ nas chapadas e $22^{\circ} \mathrm{C}$ no extremo sul. As médias das máximas variam de 30 a $36^{\circ} \mathrm{C}$, com registros de $40^{\circ} \mathrm{C}$. O inverno é ameno, cuja temperatura do mês mais frio atinge 15 a 
$24^{\circ} \mathrm{C}$, com média das mínimas variando de 8 a $18^{\circ} \mathrm{C}$ em algumas regiões. Possui alta amplitude térmica nos meses de inverno. A pluviosidade varia de 2000 a $3000 \mathrm{~mm}$ em Mato Grosso e $1500 \mathrm{~mm}$ em Goiás, com 70\% do período de chuva ocorrendo de novembro a março. O inverno nesta região é seco (PERDOMO, 1998).

A principal característica da região Norte são temperaturas médias elevadas (de $25^{\circ} \mathrm{C}$ a $27^{\circ} \mathrm{C}$ ), com chuvas abundantes (índices próximos de $2.000 \mathrm{~mm}$ anuais) e bem distribuídas no decorrer do ano, e reduzida amplitude térmica, não ultrapassando $3^{\circ} \mathrm{C}$. No inverno, essa região pode sofrer influência da massa polar atlântica, que atinge a Amazônia ocidental, ocasionando um fenômeno denominado friagem, ou seja, súbito rebaixamento da temperatura em uma região normalmente muito quente.

As médias anuais da região nordeste variam de 20 a $28^{\circ} \mathrm{C}$ no litoral e nas chapadas atinge $20^{\circ} \mathrm{C}$. No verão são registradas temperaturas máximas ao redor de $40^{\circ} \mathrm{C}$, mas no inverno ocorrem mínimas de 12 a $16^{\circ} \mathrm{C}$, caracterizado por um período curto de incidência (menor que dois dias). A irregularidade da precipitação (300 a 2000 $\mathrm{mm}$ ) e a baixa amplitude térmica são as principais características do Nordeste. Os ventos são variados (PERDOMO, 1998).

\section{Aclimatação}

Os animais trocam energia com o ambiente. Assim, podemos considerar que a ave é um sistema termodinâmico aberto em contínua troca de energia com o ambiente. Neste processo, os fatores externos tendem a produzir variações internas no animal, influindo na quantidade de energia trocada entre ambos, havendo então a necessidade de ajustes fisiológicos para a ocorrência do balanço de calor (SILVA, 2001).

A adaptação genética é um conjunto de alterações herdáveis das características que favorecem a sobrevivência de uma população de indivíduos em determinado ambiente, podendo envolver modificações evolutivas em muitas gerações (seleção natural) ou aquisição de propriedades genéticas específicas (seleção artificial).

Segundo Silva (2001) a aclimatação refere-se a mudanças adaptativas (normalmente produzidas em câmaras climáticas) em resposta a uma única variável climática. A aclimatização está relacionada aos ajustamentos fisiológicos adaptativos duradouros, que resultam em aumento de tolerância a contínuas ou repetitivas exposições a vários estressores climáticos (normalmente produzidos sob condições de campo). 
A aclimatação é um fator importante que pode exercer influência sobre o desempenho de poedeiras quando submetidas a temperaturas em condições estressantes. A capacidade das aves de sobreviverem ao estresse por calor agudo é dramaticamente aumentada pela exposição prévia do animal a altas temperaturas, contudo, esta prática é condenada nos países desenvolvidos, principalmente na União Européia.

A adaptação ao estresse pelo calor pode influenciar a resposta da ave. Segundo Yahav (2000), para sustentar a termotolerância dentro de condições deletérias do estresse de calor, duas respostas são provocadas: a resposta rápida ao choque térmico e a aclimatação.

A resposta rápida ao choque térmico pode ser induzida por condições térmicas (temperatura em torno de $37^{\circ} \mathrm{C}$ ) as quais os animais são submetidos em idade precoce, aos cinco e/ou sete dias (YAHAV et al., 1996; ZHOU et al., 1997). A técnica do condicionamento a temperaturas traz vantagens em relação maturidade dos mecanismos regulatórios da temperatura em aves jovens durante a primeira semana de vida, os quais envolvem a atividade neural simpática, a integração de informações térmicas no hipotálamo e a construção de um diferencial de temperatura entre corpo e cérebro (MODREY e NICHELMANN, 1992; SHINDER et al., 2002; SHINDER et al., 2007). O potencial de termotolerância pode ser incorporado dentro de mecanismos termorreguladores.

Os mecanismos que induzem a condição de termotolerância não estão bem esclarecidos. O longo intervalo de tempo entre a exposição térmica inicial e o desafio pelo estresse de calor em fases posteriores impede qualquer explicação para a termotolerância por conceitos relativos à fisiologia e sugerem um duradouro mecanismo de memória (YAHAV et al., 1996).

Um mecanismo que tem sido sugerido como parte da aquisição de termotolerância é a resposta da proteína de choque de calor (heat shock protein HSP) ou proteínas do estresse. As proteínas de choque térmico atuam ligando-se a outras proteínas celulares. A HSP pode entrelaçar-se dentro da estrutura secundária da proteína, prevenindo assim a desagregação durante o estresse. Tem-se proposto que a elevação da expressão da proteína de choque de calor em resposta ao estresse térmico pode contribuir para o mecanismo de aquisição de termotolerância (WANG e EDENS, 1993).

Reece et al. (1972) demonstraram que as aves podem aclimatar-se em três dias e resistir à alta mortalidade quando prostradas a temperaturas elevadas. Um grupo foi 
submetido à temperatura termoneutra $\left(21^{\circ} \mathrm{C}\right)$ e, no último, dia foram submetidas a temperatura de $40,6^{\circ} \mathrm{C}$. O outro grupo de aves foi exposto, durante três dias, a um ciclo de temperatura antes de serem submetidas à temperatura estressante de $40,6^{\circ} \mathrm{C}$. Não foi constatada nenhuma mortalidade no grupo de aves submetidas ao ciclo de temperatura. Para o grupo exposto direto a temperatura estressante de $40,6^{\circ} \mathrm{C}$, a mortalidade foi de 33\%. Em estudo semelhante realizado por Deaton et al. (1982), as aves aclimatadas apresentaram ovos de qualidade superior às aves submetidas a um estresse severo de $39^{\circ} \mathrm{C}$.

Em revisão sobre aclimatação a altas temperaturas foi constatado que o processo está associado principalmente a baixa taxa metabólica nessas condições. Contudo não foi possível obter claramente quais mecanismos estão envolvidos neste processo (SMITH e OLIVER, 1971).

Efeitos do estresse por calor sobre os parâmetros produtivos

Vários fatores determinam a qualidade do ovo na granja, tais como, qualidade da casca, idade, origem genética e condição sanitária das galinhas, além da duração e das condições de armazenamento (BENABDELJELIL e RYADI,1991).

A avaliação da qualidade interna de ovos é realizada através de parâmetros físicos, químicos, biológicos e funcionais. A linhagem, idade, alimentação, temperatura, umidade relativa e duração do armazenamento, doenças e até mesmo a manipulação e a coleta automática de ovos, são fatores que exercem influência na qualidade interna dos ovos (CEPERO et al., 1995; BERARDINELLI et al., 2003).

O albúmen exerce influência na qualidade do ovo, controlando a posição da gema no ovo intacto. A posição e o movimento da gema são indicações importantes da qualidade interna do ovo. Dentro do ovo intacto, o albúmen consiste de camadas concêntricas de gel incolor e líquido. Quando um ovo fresco é cuidadosamente quebrado em uma superfície homogênea e plana, a gema se mostrará túrgida e localizada centralmente, circundada pelo albúmen denso e delgado. Quando um ovo velho é quebrado, a gema se apresentará flácida, frequentemente localizada em um lado, e circundada por uma área ampla de líquido (SOLOMON, 1991; OVERFIELD e BRIZ, 1995).

Diversos autores avaliaram a influência da temperatura ambiental sobre a produção de ovos (PAYNE, 1966; MOWBRAY e SYKES, 1971; MARSDEN e MORRIS, 1975; CHARLES et al.,1976; HVIDSTEN e HAUGEN, 1977; VOHRA et al., 1979; CARMO,1981). Nestas pesquisas foram constatadas que, à medida que se 
elevava a temperatura ambiental, havia redução da ingestão voluntária de alimento nas poedeiras.

Sevegnani et al. (2005) avaliaram o comportamento de frangos de corte com diferentes idades submetidos a diversas combinações de temperatura e umidade em câmara climática. Os resultados mostraram que, em aves com idade mais avançada há maior ingestão de água e menor ingestão de ração à medida em que a temperatura é elevada.

Frente à exposição de elevadas temperaturas, as aves tendem a diminuir a ingestão, pois o alimento aumenta o metabolismo e, consequentemente, a quantidade de calor corporal. A redução de consumo alimentar remove substratos metabólicos e constitui um importante meio de reduzir a carga calórica. Porém, a redução do consumo de ração e, consequente diminuição na ingestão de nutrientes afeta diretamente a produtividade do lote, culminando na redução do ganho de peso e do bem-estar das aves (TEETER, 1989).

Segundo pesquisas realizadas por Payne (1967), a redução na produção de ovos em temperaturas elevadas pode ser associada à diminuição na ingestão de nutrientes essenciais, resultado da diminuição do consumo.

A qualidade da casca é um parâmetro relevante para a avaliação da qualidade de ovos, visto que, ocorrem grandes perdas na produção devido a ovos quebrados (HAMILTON, 1982; SOLOMON, 1991).

Outro fator importante relacionado à integridade da casca está relacionado com a incidência e contaminação por bactérias ou, ainda, pela constatação da presença de coliformes. Saulter e Petersen (1974) constataram que ovos com baixos valores de gravidade específica foram mais susceptíveis a penetração por Salmonella.

Segundo Howlider e Rose (1987), a temperatura exerce importância no crescimento, consumo de alimento e na composição corporal de frangos de corte. Esses mesmos autores constataram que, em ambientes quentes, parece haver redução na taxa metabólica e atividade física das aves, com maior armazenamento de gordura. Em suas pesquisas verificaram aumento de $0,8 \%$ no conteúdo de lipídeos do corpo e $1,6 \%$ da gordura abdominal, quando a temperatura foi elevada de 21 para $29^{\circ} \mathrm{C}$.

O Capítulo 2, denominado EFEITO DO ESTRESSE CONTÍNUO PELO CALOR SOBRE O DESEMPENHO E A QUALIDADE DOS OVOS DE CODORNAS JAPONESAS apresenta-se de acordo com as normas para publicação na revista 
Brazilian Journal of Poultry Science e teve como objetivo avaliar o efeito da temperatura sobre o desempenho e a qualidade de ovos de codornas japonesas na fase de pós-pico de produção.

O Capítulo 3, denominado DESEMPENHO E QUALIDADE DE OVOS DE CODORNAS JAPONESAS SOB ESTRESSE CíCLICO PELO CALOR apresenta-se de acordo com as normas para publicação na revista Brazilian Journal of Poultry Science e teve como objetivo avaliar o efeito da temperatura cíclica sobre as características de desempenho e qualidade de ovos de codornas japonesas, alojadas em câmara bioclimática, na fase de pós-pico de produção. 


\section{REFERÊNCIAS}

ABREU, V. M. A.; ABREU, P.G. Diagnóstico bioclimático para produção de aves na mesorregião centro sul baiano. Concórdia: EMBRAPA suínos e aves, 2003. 11 p.

ALVAREZ, R.; DELGADO, C. Condiciones de confort para la explotación de las gallinas ponedoras. Revista Cubana de Ciência Avícola, La Habana, v. 24, p. 1-13, 2000.

ALVES, S. P.; SILVA, I. J. O.; PIEDADE, S. M. S. Avaliação do bem-estar de aves poedeiras comerciais: efeitos do sistema de criação e do ambiente bioclimático sobre o desempenho das aves e a qualidade de ovos. Revista Brasileira de Zootecnia, Viçosa, v. 36, n. 5, p. 1388-1394, 2007.

AMERICAN SOCIETY OF HEATING AND REFRIGERATION AND AIR CONDITIONED ENGINEERS. Handbook of fundamentals. Environment, New York, p. 139-198, 1985.

AVICULTURA INDUSTRIAL. Exportação de ovos para os países árabes quintuplicaram. Disponível em:

<http://www.aviculturaindustrial.com.br/PortalGessulli/WebSite/Noticias/exportacao-deovos-para-os-paises-arabes-quintuplicaram,36788,20081118090935_B_868.aspx Acesso em: 1 out. 2009.

BAETA, F. C. Sistema de ventilação natural e artificial na criação de aves. In: SIMPÓSIO INTERNACIONAL SOBRE AMBIÊNCIA E SISTEMA DE PRODUÇÃO AVÍCOLAS, 55, Concórdia, 1998. Anais... Concórdia: EMBRAPA, 1998. p. 96-117.

BAIÃO, N. C. Efeitos da alta densidade populacional sobre o ambiente das instalações avícolas. In: SMPÓSIO INTERNACIONAL SOBRE AMBIÊNCIA E INSTALAÇÕES NA AVICULTURA INDUSTRIAL, 1995, São Paulo, Anais... Campinas: FACTA, p. 67-75.

BARROT, H. G.; PRINGLE, E. M. The effects of temperature of environment during the first nine days after hatch. Journal of Nutrition, Bethesda, v. 39, p. 153-161, 1949.

BENABDELJELIL, K.; RYADI, A. Egg quality: a preliminary case study. Bulletin of animal Health and Production in Africa, Grahamstown, v. 39, n. 2, p. 143-147, 1991.

BENNION, N. L.; WARREN, D.C. Temperature and its effect on egg size in the domestic fowl. Poultry Science; Champaign, v. 12, p. 69-82, 1933.

BERARDINELLI, A. et al. Effects of transport vibrations on quality indices of shell eggs. Biosystems Engineering, v. 86, n. 4, p. 495-502, 2003. 
BORGES, S. A. et al. Suplementação de cloreto de potássio para frangos de corte submetido a estresse calórico. Revista Brasileira de Zootecnia, Viçosa, v. 28, n.2, p. 313-319, 1999.

BORGES, S.A. et al. Balanço eletrolítico para frangos de corte na primeira semana de idade. Revista Brasileira de Ciência Avícola, Campinas, v.4, n.2, p.149-153, 2002.

CARMO, M. B. Níveis de proteína e de aminoácidos sulfurosos em rações de galinhas poedeiras sob regime de alta temperatura. 1981. 75p. Dissertação (Mestrado em Zootecnia), Universidade Federal de Viçosa, Viçosa, 1981.

CHARLES, D. R.; EMMANS, G. D.; DUN, P. Studies on the interaction between temperature and nutrition for layers, Gledthorpe, Poultry Husbandry Experimental Unit Booklet, U.K. 1976.

CEPERO, R. et al. Effects of transport and storage conditions on the commercial quality of eggs. In: BRIZ, R. C. Egg and egg products quality. Zaragoza: Acribia, 1995. $429 \mathrm{p}$.

COSTA, M. S. Efeito das condições ambientais tropicais na fisiologia e rendimento das poedeira, métodos para diminuir os efeitos prejudiciais das condições ambientais tropicais. In: AVICULTURA NAS REGIÕES TROPICAIS. Campinas: Fundação Cargil. 1980. 121p.

DEATON, J. W.; MCNAUGHTON, I. L.; LOTT, B. D. Effect of heat stress on laying hens acclimated to cyclic versus constant temperatures. Poultry Science, Champaign, v. 61 , p. $875-882,1982$.

FRASER, D.; RITCHIE, J.S.D.; FRASER, A.F. The term "stress" in a veterinary context. British Veterinary Journal, Newmarket Suffolk, v.13, n.1, p.653-62, 1975.

FREEMAN, R. M., COGBURN, S. Response of daily thyroid rhythms to cyclic temperature. Poultry Science, Champaign, v. 62, p. 1425, 1983. Supplement.

FREEMAN, B. M. The domestic fowl in biomedical research: physiological effects of the environment. World's Poultry Science Journal, Cambridge, v. 44, p. 44-60, 1988.

FURLAN, R. L. et al. Alterações hematológicas e gasométricas em diferentes linhagens de frangos de corte submetidos ao estresse calórico agudo. Revista 
Brasileira de Ciência Avícola / Brazilian Journal of Poultry Science, Campinas, v. 01, n. 01, p. 77-84, 1999.

FURLAN, R. L. Produtividade vs comportamento animal. In: CONGRESSO DE PRODUÇÃO, COMERCIALIZAÇÃO E CONSUMO DE OVOS, 7., 2009. São Pedro. Anais... São Pedro: APA, 2009, p. 124-141.

HAMILTON, R. M. G. Methods and factors that affect the measurement of egg shell quality. Poultry Science, Champaign, v. 61, p. 2022-2039, 1982.

HOWLIDER, M. A. R.; ROSE, S. P. Temperature and the growth of broilers. Worlds' Poultry Science Journal, Cambridge, v. 43, n. 228-237, 1987.

HVIDSTEN, H.; HAUGEN, A. E. Influence of temperature on laying performance. Poultry International, Nov. p. 62-65. 1977.

INSTITUTO BRASILEIRO DE GEOGRAFIA E ESTATÍSTICA. Disponível em < http://www.ibge.gov.br>. Acesso em: 08/out./2009.

JOINER, W. P.; HUSTON, M. R. The influence of high environmental temperatures on immature domestic fowl. Poultry Science, Champaign, v. 36, n. 8, p. 973-978, 1957.

KASSIM, H.; SYKES, A. H. The respiratory responses of the fow to hot climates. The Journal of Experimental Biology, Washington, v. 97, n. 1, p. 301-309, 1982.

LESSON, S.; SUMMERS, J. D. Commercial poultry nutrition, Nottingham. Guelph: University Books, 1991. 283 p.

LINSLEY, J. G.; BERGER, R. R. Respiratory and cardiovascular responses in the hyperthermic domestic cock. Poultry Science, Champaign, v. 43, p. 291-305, 1964.

MACARI, M.; FURLAN, R. L., GONZALES, E. Fisiologia aviária aplicada a frangos de corte. Jaboticabal: FUNEP; UNESP, 1994. 246 p.

MACARI, M. Água de beber na dose certa. Aves \& Ovos. São Paulo, APA- Associação Paulista de Avicultura. Ano XI, n. 6, abril, p. 40-48, 1995.

MANNING, A. An introduction to animal behaviour. Reding: Addiosn-Wesley, Reding, M. A.; 1972, 329 p. 
MARSDEN, A.; MORRIS, T. R. Comparisons between constant and cyclic environments on shell quality and other lay performance factors with Leghorn pullets. Poultry Science, Champaign, v. 54, n. 36-46, 1975.

MENCH, J. A. Broiler breeders: Feed restriction and welfare. World's Poultry Science Journal, Cambridge, v. 58, p. 27-33, 2002.

MITCHELL, M. A. Some physiological effects of environmental temperature upon poultry temperature stress and convective cooling in laying hens. In: INTERNATIONAL

POULTRY BREEDERS CONFERENCE, 3., 1987. Proceedings. Scotland., 1987. p. 2425.

MODREY, P.; NICHELMANN, M. Development of autonomic and behavioral thermoregulation in turkeys (Meleagris gallopavo). Journal of Thermal Biology, Amsterdam, v. 17, p. 287-292, 1992.

MOWBRAY, R. M.; SYKES, A. H. Egg production in warm environmental temperatures. British Poultry Science, London, v.12, p. 25-29. 1971

NORTH, M.; BELL, D. Comercial chicken production: manual. 4th ed. New York: Van Nostrand Reinol, 1990. 425 p.

ODOM, T. W ; HARRISON, P. C. ; BOTTJE, W. G. Effects of thermal induced respiratory alkalosis on blood ionized calcium levels in the domestic hen. Poultry Science, Champaign, v. 45, p. 1386-1370, 1986.

OLIVEIRA, B. L. Manejo m granjas automatizadas de codornas de postura comercial. In: SIMPÓSIO INTERNACIONAL, 3.; CONGRESSO BRASILEIRO DE COTURNICULTURA, 2., 2007. Lavras, Anais... Lavras: UFV, 2007, p. 11-16.

OVERFIELD, N. D.; BRIZ, R. C. Egg quality assessment techniques at laboratory and field level. In: EGG AND EGG PRODUCTS QUALITY. Zaragoza: 1995, 429 p.

PAYNE, G. C. Pratical aspects of environmental temperature for laying hens. World's Poultry Science Journal, Cambridge, v. 22, p. 126-139, 1966.

PAYNE, C. G. Environmental control of poultry production. London: Longmans, 1967, $45 \mathrm{p}$. 
PERDOMO, C. C. Mecanismos de aclimatação de frangos de corte como forma de reduzir a mortalidade no inverno e verão. In: CONFERÊNCIA APINCO DE CIÊNCIA E TECNOLOGIA AVÍCOLAS,1998, Campinas. Anais... Campinas, FACTA, 1998, p. 229240.

REECE, F. N.; DEATON, J. W., KUBENA, L. F. Effects of high temperature and humidity on heat prostration of broiler chickens. Poultry Science, Champaign, v. 51, p. 202-211, 1972.

ROLLER, W. L.; STOMBAUGH, D. P. The influence environmental factors on the reproduction of livestock. In: INTERNATIONAL SYMPOSIUM LIVESTOCK

ENVIRONMENT, 1976. Atlanta. Proceedings. Atlanta, v.1, 1976. p. 31-50.

SARTORI, J. R. Medidas alternativas de manejo para o controle do estresse calórico. In: SEMANA DE CIÊNCIA E TECNOLOGIA AGROPECUÁRIA, 1996, Jaboticabal. Anais... Jaboticabal: SECITAP, Anais... 1996. p.1-15.

SAULTER, E. A; PETERSEN, C. F. The effect of egg shell quality on penetration by various Salmonellae. Poultry Science, Champaign, v. 53 , p. 2159-2162, 1974.

SEVEGNANI, K. B. et al. Zootecnia de precisão: análise de imagens no estudo do comportamento de frangos de corte em estresse térmico. Revista Brasileira de Engenharia Agrícola e Ambiental, Campina Grande, v. 9, n. 1, p. 115-119, 2005.

SHINDER, D. et al. Early age cold conditioning in broiler chickens (Gallus domesticus): Thermotolerance and growth responses. Journal of Thermal Biology, Amsterdam, v. 27, p. 517-523, 2002.

SHINDER, D. et al. Thermoregulatory responses of chicks (Gallus domesticus) to low Ambient temperatures at an early age. Poultry Science, Champaign, v. 86, p. 2200 2209, 2007.

SILVA, I. J. O.; NÃ̃̃S, I. A.; BUCKLN, R. A. Evaluation of egg production housing in hot climate. Paper ASAE, n. 94.4567, p. 1-8, Atlanta: ASAE,1994.

SILVA, I. J. O. Ambiência na produção de aves em clima tropical. Piracicaba: FUNEP, 2001. v. 2, 214 p.

SILVA, M. A.N. et al. Avaliação do estresse térmico em condição simulada de transporte de frangos de corte. Revista Brasileira de Zootecnia, Viçosa, v. 36, n. 4, p. 1126-1130, 2007. 
SMITH, C. V. A quantitative relationship between environment, comfort and animal productivity. Agricultural Meteorology, Geneva, v. 1, p. 249-270, 1964.

SMITH, A. J.; OLIVER, J. Some physiological effects of high environmental temperatures on the laying hen. Poultry Science, Champaign, v.5, p.912, 1971.

SOLOMOM, S. E. Egg and eggshell quality. London: Wolfe, 1991. 149 p.

TEETER, R. G. Otimização da produtividade em frangos de corte durante o estresse calórico. Simpósio Técnico Planalquímica, v. 1, p. 17-40, 1989.

VOHRA, P.; WILSON, W. O.; SIOPES, I. D. Egg production, feed consumption and maintenance energy requirements of Leghorn hens as influenced by dietary energy at temperatures of 15,6 and $26,7^{\circ} \mathrm{C}$. Poultry Science, Champaign, v. 58, p. $674-680$, 1979.

VON BORELL, E. Neuroendocrine integration of stress and significance of stress for the performance of farm animals. Applied Animal Behaviour Science, Cambridge, $v$. 44, p. 219-227, 1995.

WANG, S.; EDENS, F.W. Stress-induced heat stock protein synthesis in peripheral leukocytes of turkeys (Memeagris gallopava). Compendium of Biochemistry Physiology. Philadelphia ,v. 106, p. 631-628, 1993.

YAHAV, S. et al. Effects of diurnally cycling versus constant temperatures on chickens growth and food intake. British Poultry Science, London, v. 37, p. 43-54, 1996.

YAHAV, S. Intensive Poultry Production. Shefayin: Israel, 2000. p. 1-6.

ZANOLLA, N. Sistemas de ventilação em túnel e sistema de ventilação lateral na criação de frangos de corte em alta. 1998. 81 p. Dissertação (Mestrado em Construções Rurais e Ambiência) - Universidade Federal de Viçosa, Viçosa, MG, 1998.

ZHOU, W. T.et al.. Effects of early heat exposure on thermoregulatory responses and blood viscosity of broilers prior to marketing.British Poultry Science, London, v. 38, p. 301-306, 1997. 
CAPÍTULO 2 


\title{
EFEITO DO ESTRESSE CONTÍNUO PELO CALOR SOBRE O DESEMPENHO E A QUALIDADE DOS OVOS DE CODORNAS JAPONESAS
}

\begin{abstract}
RESUMO
Com o objetivo de avaliar o efeito da temperatura sobre o desempenho e qualidade de ovos de codornas japonesas foi realizado um experimento utilizando-se 480 aves na fase de pós-pico de produção. As aves foram alojadas em uma câmara bioclimática com controle automático de temperatura, contendo duas baterias compostas de cinco andares e dez gaiolas, com capacidade para 24 aves cada gaiola, divididas em dois grupos: 240 aves no grupo controle $\left(21^{\circ} \mathrm{C}\right)$ e 240 aves no grupo experimental, com temperaturas contínuas de $24,27,30,33$ e $36^{\circ} \mathrm{C}$ em períodos de 14 dias. O período experimental, com duração de 105 dias, foi dividido em cinco ciclos de 21 dias (um ciclo para cada temperatura), sendo 14 dias na temperatura teste e sete dias na temperatura termoneutra. No final de cada ciclo experimental foi avaliado o desempenho e a qualidade dos ovos. Para todos os tratamentos, as rações foram isonutritivas e isocalóricas. Para a avaliação do desempenho e da qualidade dos ovos utilizou-se um delineamento inteiramente casualisado com dois tratamentos (temperatura termoneutra e temperatura teste) e dez repetições de 24 aves por parcela. A elevação da temperatura piora o consumo de ração, reduz o peso dos ovos, a produção e a massa de ovos. Em temperaturas superiores a $27^{\circ} \mathrm{C}$ houve piora na qualidade interna e externa dos ovos.
\end{abstract}

Palavras-chave: Coturnix coturnix japonica, estresse por calor, pós-pico de produção, produção de ovos, temperatura ambiente. 


\title{
EFFECT OF CONTINUOUS TEMPERATURE ON THE PERFORMANCE AND QUALITY OF EGGS JAPANESE QUAILS
}

\begin{abstract}
In order to evaluate the effect of temperature on performance and egg quality of Japanese quails was conducted an experiment using 480 birds in the post-peak production. The birds were housed in a climate chamber with automatic temperature control, with two batteries composed of five floors and ten cages for up to 24 birds in each cage, divided into two groups: 240 birds in the control group $\left(21^{\circ} \mathrm{C}\right)$ and 240 birds in the experimental group, which temperatures of $24,27,30,33$ and $36^{\circ} \mathrm{C}$. The experiment, lasting 105 days, was divided into five 21-day cycles (one cycle for each temperature), and 14 days at test and seven days a thermoneutral. At the end of each experimental cycle was evaluated performance and egg quality. For all treatments, the diets were isocaloric and isonutritives. For the evaluation of performance and quality of eggs used a completely randomized design with two treatments (temperature and thermoneutral temperature test) and ten replicates of 24 birds per plot. Elevated temperature worsens the feed intake, egg weight, production and egg mass. At temperatures above $27^{\circ} \mathrm{C}$ worsened the internal and external quality of eggs.
\end{abstract}

Keywords: Coturnix coturnix japonica, eggs' production, heat stress, post-peak production, temperature 


\section{INTRODUÇÃO}

No cenário da produção avícola brasileira, durante muitos anos, a coturnicultura foi considerada como atividade alternativa para pequenos produtores. Entretanto, em função do potencial dessas aves para produção de ovos e carne e da possibilidade de diversificação para a comercialização desses produtos, a exploração comercial de codornas cresceu muito nos últimos anos e ainda se encontra em expansão.

A criação de codornas desperta interesse em virtude de seus inúmeros aspectos positivos. O pequeno porte, a rusticidade, o curto ciclo reprodutivo, a precocidade e a produtividade são fatores motivadores e atraentes para criadores amantes das aves, mas sempre estruturados para atividade como negócio (Oliveira, 2002).

O manejo adequado é muito importante, pois complementa as práticas sanitárias e de alimentação e interfere diretamente nos principais índices zootécnicos, especialmente na viabilidade, ritmo de crescimento, eficiência das rações e produtividade.

É importante salientar que qualquer alteração no ambiente ou na rotina são facilmente percebidas pelas codornas, atuando como fatores estressantes, sendo que as respostas a estes fatores quase sempre são notadas através da redução na produção de ovos, aumento na taxa de ovos quebrados e redução do consumo de ração (Oliveira, 2002).

A homeostase se caracteriza pela manutenção do equilíbrio orgânico, mesmo com a variação das condições ambientais. Trata-se das propriedades que alguns animais (aves e mamíferos), bem como o homem, possuem de manter a temperatura corporal constante, ou variando dentro de estreitos limites, enquanto a temperatura externa tem variações apreciáveis (Rodrigues, 2006).

O equilíbrio da temperatura corpórea em animais homeotermos se dá pelo balanço energético em que a produção de calor metabólico é igual a perda de calor para o ambiente, desde que a temperatura ambiente esteja dentro dos limites da termoneutralidade (Silva \& Sevegnani, 2001). O balanço entre os mecanismos de produção e perda de calor faz com que a temperatura corporal permaneça estável, sendo regulada por meio de mecanismos fisiológicos e também comportamentais, sempre que o centro termorregulador detecta variações do ambiente térmico com o objetivo de equilibrar o calor produzido e perdido ou ganho para o meio ambiente.

Segundo Murakami \& Ariki (1998), a zona de termoneutralidade para codornas na fase inicial está entre 35 a $38^{\circ} \mathrm{C}$ e na fase de postura entre 18 e $22^{\circ} \mathrm{C}$. 
A temperatura ambiental ótima é variável conforme a fase de criação. Muitas vezes, principalmente em criações intensivas, é necessário adotar medidas para assegurar o resfriamento no interior dos galpões quando a temperatura atinge valores extremos. Em países e regiões localizadas na zona tropical climática a manutenção da temperatura ótima é um dos maiores desafios, com investimentos significativos para manutenção da temperatura em níveis adequados. Portanto, pesquisas avaliando os efeitos de temperaturas elevadas em aves e suas possíveis soluções são motivos de grande importância e preocupação (Poyraz et al., 1991).

O ambiente pode ser definido como a soma dos impactos dos circundantes biológicos e físicos e constitui-se em um dos responsáveis pelo sucesso ou fracasso do empreendimento avícola. Isso porque, na maioria dos casos, as aves domésticas são confinadas, proporcionando pouca margem de manobra para os ajustes comportamentais necessários para manutenção da homeostase térmica. Portanto, considerando que, na maioria dos sistemas de produção de aves da América Latina, os fatores climáticos são pobremente manipulados e gerenciados, o microambiente para produção e bem-estar das aves nem sempre é compatível às necessidades fisiológicas das mesmas. Os efeitos estressores do ambiente podem estar vinculados à velocidade e temperatura do ar, temperatura radiante, disponibilidade de água, umidade da cama, etc. (Macari et al., 1994).

Considerando-se o micro-clima de confinamento, quando há mudanças na temperatura do ambiente, os animais apresentam várias respostas para manter a temperatura do corpo, começando com a conservação máxima de energia através da inatividade (Darre \& Harrison, 1987; Freeman, 1965).

Em climas tropicais e subtropicais como no Brasil, a radiação solar intensa e a elevada temperatura e umidade relativa do ar no verão geram desconforto térmico quase permanente às aves, prejudicando seu desempenho produtivo e tornando-se um dos principais problemas que afetam a exploração avícola (Tinôco, 1994). Na zona termoneutra, no entanto, as aves despendem pouca energia para manter sua homeotermia, de modo que praticamente toda energia assimilada da dieta é destinada aos processos produtivos.

As variáveis ambientais tanto podem ter efeitos positivos como negativos sobre a produção das aves. Assim, altas temperaturas reduzem o consumo de alimento prejudicando o desempenho. Já, baixas temperaturas podem melhorar o ganho de peso, mas à custa de elevada conversão alimentar. Nesse sentido, a condição ambiental deve ser manejada, na medida do possível, para evitar os efeitos negativos 
sobre o desempenho produtivo das aves, com consequente efeito sobre a produção animal - carne e ovos (Macari et al., 1994).

Estudos sobre genética, nutrição e manejo vem sendo desenvolvidos para melhorar cada vez mais o conforto térmico animal, sendo que as condições ambientais também devem ser manejadas na medida do possível, para evitar efeitos negativos sobre o desempenho produtivo das aves.

Assim, para se obter melhor desempenho produtivo na avicultura, deve-se estar atento à interação entre o animal e o ambiente, a fim de que o custo energético dos ajustes fisiológicos sejam os menores possíveis (Macari et al., 1994). Visando a melhoria na produtividade da espécie Coturnix coturnix japonica, o projeto teve como objetivo avaliar o efeito do estresse contínuo pelo calor sobre o desempenho e a qualidade dos ovos.

\section{MATERIAL E MÉTODOS}

O experimento foi conduzido na Unesp - Faculdade de Medicina Veterinária e Zootecnia/Campus Botucatu/SP, na Câmara Climática, durante os meses de agosto a dezembro de 2008. Foram utilizadas 480 codornas japonesas (Coturnix coturnix japonica) na fase de pós-pico de produção (21 semanas de idade), selecionadas de acordo com o peso corporal e produção de ovos, para se obter um lote homogêneo e reduzir possíveis efeitos individuais. Após a seleção, as aves foram alojadas em duas câmaras climáticas para um período de adaptação (correspondente a três meses) e, posteriormente, início do período experimental.

As câmaras climáticas possuíam 4,30 m de comprimento por 4,50 m de largura e 2,60 m de altura. Cada câmara continha uma bateria de gaiolas, com capacidade para 240 aves. Cada bateria composta de cinco andares, com duas gaiolas por andar, com $100 \mathrm{~cm}$ de comprimento por $34 \mathrm{~cm}$ de largura e $16 \mathrm{~cm}$ de altura. As gaiolas foram equipadas com comedouros, de chapa metálica galvanizada, e bebedouros tipo calha. Foi utilizada uma taxa de lotação de 24 aves por gaiola, sendo quatro aves/compartimento, obtendo-se uma densidade de 141,67 cm²/ave (Figuras 1A e 1B).

O delineamento experimental foi inteiramente casualizado, constituído de dois tratamentos com dez repetições de 24 aves por parcela. O período experimental total foi dividido em cinco ciclos de 21 dias (um ciclo para cada temperatura teste), sendo a coleta de dados efetuada durante 14 dias, seguido por um período de descanso para as aves, de sete dias, em temperatura termoneutra $\left(21^{\circ} \mathrm{C}\right)$ para que os dados de 
produção das aves da sala teste se equiparassem aos das aves na sala em temperatura termoneutra. Do total de aves utilizadas, 240 codornas constituíram o grupo controle $\left(21^{\circ} \mathrm{C}\right)$ e as 240 aves restantes, o grupo experimental, que foi submetido às temperaturas teste de $24,27,30,33$ e $36^{\circ} \mathrm{C}$, em cada período. As temperaturas eram mantidas sem interrupções. Os resultados obtidos no grupo experimental, para cada temperatura teste, foram comparados aos dados observados no grupo controle $\left(21^{\circ} \mathrm{C}\right)$, com as aves possuindo a mesma idade.
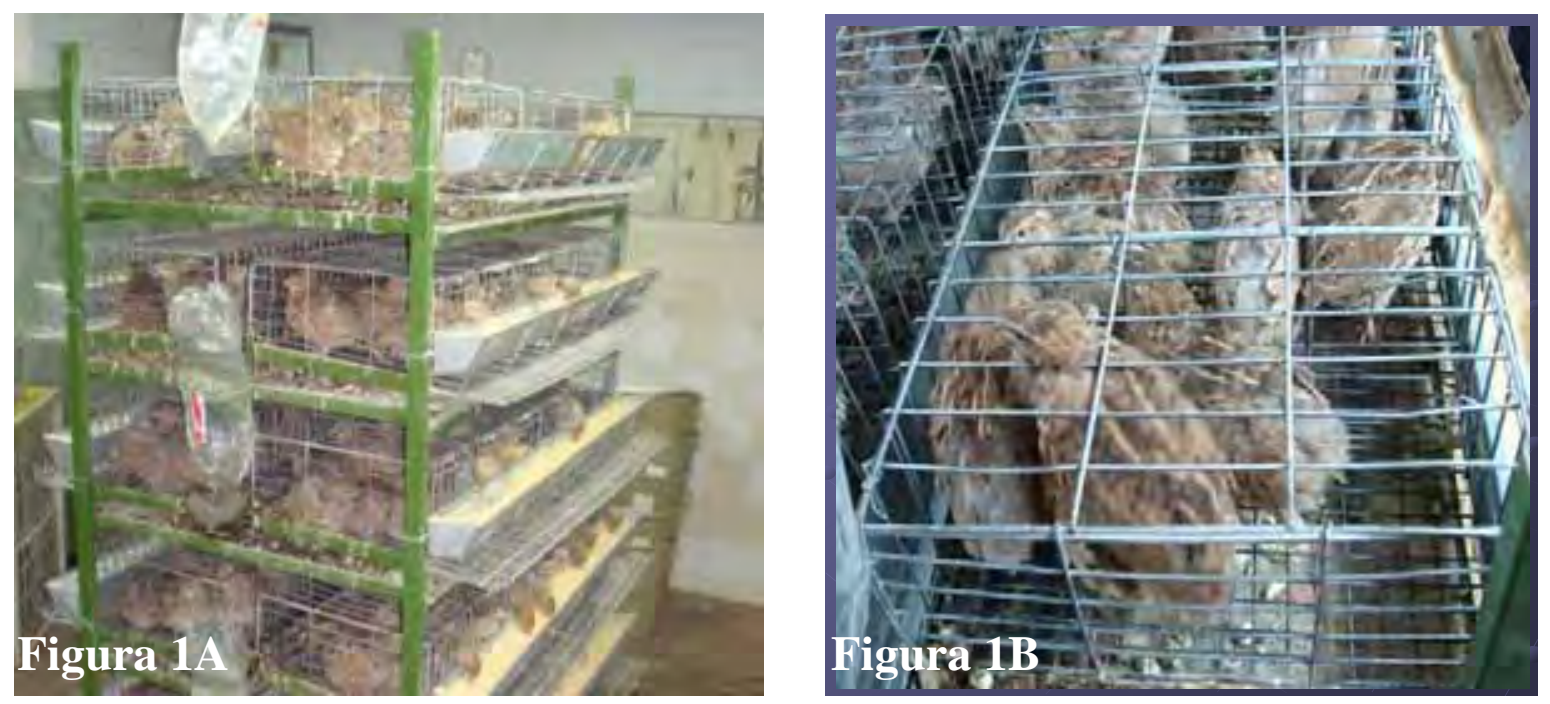

Figuras 1A e 1B - Disposição da bateria na câmara bioclimática e detalhe da gaiola.

Foi utilizado um programa de luz de 17 horas diárias. Durante todo o período experimental, as aves foram submetidas a idêntico manejo alimentar, sendo fornecidas água e ração à vontade. $\mathrm{O}$ arraçoamento foi realizado duas vezes ao dia. As dietas foram isonutritivas, compostas por milho e farelo de soja, fornecendo $2.800 \mathrm{kcal}$ de $\mathrm{EM} / \mathrm{kg}$ de ração, $20 \%$ de proteína bruta, $3,2 \%$ de cálcio, $0,35 \%$ de fósforo disponível, $0,45 \%$ de metionina, $0,76 \%$ de metionina + cistina e $1,07 \%$ de lisina, de acordo com as exigências nutricionais propostas pelo NRC (1994).

$\mathrm{O}$ aquecimento das salas foi realizado com o auxílio de três aquecedores elétricos acoplados a um termostato e o resfriamento através da utilização de aparelhos de ar condicionado, dotados de controle automático de temperatura. Os valores de temperatura e umidade relativa do ar (máxima e mínima) foram obtidos através de um termo-higrômetro para cada câmara e anotados diariamente em formulários próprios. 
As características de desempenho avaliadas foram: consumo de ração, percentagem de postura, percentagem de ovos viáveis, peso médio dos ovos, massa de ovos, conversão alimentar por dúzia e por quilograma de ovos produzidos. Diariamente, foram anotados o número de ovos inteiros e quebrados para posterior cálculo da percentagem de postura e de ovos viáveis.

O consumo de ração por ave foi determinado semanalmente através da diferença entre a quantidade fornecida diariamente e as sobras existentes no final de cada período de sete dias. O resultado foi dividido pelo número médio de aves de cada parcela e expresso em gramas por ave por dia.

A percentagem de postura foi obtida dividindo-se o número total de ovos postos por gaiola na semana pelo número médio de aves multiplicado por sete, e o resultado multiplicado por 100. O percentual de ovos viáveis foi obtido pelo número total de ovos viáveis produzidos na semana, dividido pelo número total de ovos produzidos e o resultado multiplicado por 100 .

Os ovos viáveis foram pesados semanalmente. O peso médio foi obtido dividindo-se o peso total dos ovos das gaiolas pelo número de ovos das mesmas e o resultado expresso em gramas. A massa de ovos produzida foi obtida multiplicando-se a percentagem de ovos postos no período pelo peso dos ovos postos no mesmo período, o valor obtido foi expresso em gramas/ave/dia.

A conversão alimentar por dúzia de ovos produzidos foi mensurada semanalmente, dividindo-se o peso total da ração consumida na parcela, expresso em quilogramas, pelo respectivo número de dúzias de ovos produzidos na semana. A conversão alimentar por quilograma de ovos produzidos foi mensurada a cada semana, dividindo-se o peso total da ração consumida, expressa em quilogramas, pelo peso dos ovos postos no período, também expresso em quilogramas.

A análise da qualidade dos ovos foi efetuada, para cada temperatura, ao final dos 14 dias de coleta de dados, durante três dias consecutivos. A cada dia foi coletada uma amostra de dois ovos por parcela, perfazendo um total de 60 ovos por temperatura avaliada. No último dia de cada ciclo foram coletadas quatro amostras de ovos para análise do conteúdo de sólidos totais.

As características de qualidade dos ovos avaliadas foram: gravidade especifica, percentagens de gema, albúmen e casca, índice gema, espessura da casca, resistência da casca à quebra e unidade Haugh. A gravidade específica dos ovos foi calculada segundo metodologia descrita por Staldelman \& Cotterill (1990). 
As percentagens de gema, albúmen e casca foram obtidas dividindo-se os respectivos pesos pelo peso do ovo e o resultado multiplicado por 100 . O índice gema foi calculado dividindo-se a altura da gema pelo diâmetro da mesma, sendo que a altura da gema foi obtida através de um micrômetro, sendo mensurada na região mediana e o valor expresso em milímetros.

A espessura da casca foi mensurada através da utilização de um paquímetro digital, tomando-se três medidas na zona equatorial do ovo, após as cascas serem secas em estufa durante três dias, sob temperatura de $60^{\circ} \mathrm{C}$. As espessuras foram expressas em milímetros.

A resistência da casca à quebra foi determinada na região equatorial do ovo com o auxílio de um texturômetro TA.XT Plus - Texture Analyser utilizando-se sonda de ruptura de $2 \mathrm{~mm}$, velocidade de pré-teste de $2 \mathrm{~mm} /$ segundo; velocidade do teste 1,0 $\mathrm{mm} / \mathrm{segundo}$ e velocidade pós-teste de $40 \mathrm{~mm} / \mathrm{segundo}$, a qual registrou a força necessária para romper a casca e o resultado expresso em gramas.

Para o cálculo da unidade Haugh, foi determinada inicialmente a altura do albúmen, com auxílio de um paquímetro digital sendo efetuado, posteriormente, o cálculo empregando-se a fórmula descrita por Stadelman \& Cotterill (1990): UH = 100 $\log \left(\mathrm{H}+7,57-1,7 \mathrm{~W}^{0,37}\right)$ sendo, $\mathrm{H}=$ altura do albúmen $(\mathrm{mm}) ; \mathrm{W}=$ peso do ovo $(\mathrm{g})$; 7,57= fator de correção para altura do albúmen; 1,7= fator de correção para peso do ovo.

Os teores de sólidos totais foram determinados separadamente no albúmen e na gema. Foram pesados um pool de gema e um pool de albúmen de quatro ovos em cadinhos de porcelana previamente secos em estufa de $105^{\circ} \mathrm{C}$, para retirada da umidade, durante 48 horas. Os cálculos utilizados para a determinação da umidade $e$ dos sólidos totais foram: Teor de umidade $(\mathrm{g} / 100 \mathrm{~g})=\underline{(\mathrm{A}-\mathrm{B})} \times 100$, sendo

C

$A=$ peso do recipiente e amostra; $B=$ peso do recipiente e amostra após secagem e $C=$ peso da amostra. Teor de sólidos totais $(\mathrm{g} / 100 \mathrm{~g})=100-$ teor de umidade $(\mathrm{g} / 100 \mathrm{~g})$

A análise estatística dos resultados foi realizada com o auxílio do programa estatístico SISVAR, de acordo com Ferreira (1998). Os resultados foram avaliados através da análise de variância e as médias foram comparadas pelo teste de Tukey a $5 \%$ de significância. 


\section{RESULTADOS E DISCUSSÃO}

As médias de temperatura e umidade relativa do ar (máxima e mínima), durante cada ciclo, são apresentadas na Tabela 1.

Tabela 1. Médias de temperaturas máxima ( $T M A X)$ e mínima ( $T$ MIN) e umidade relativa do ar máxima (UR MAX) e mínima (UR MIN) nas câmaras climáticas.

\begin{tabular}{lcccccc}
\hline & Termoneutra & \multicolumn{5}{c}{ Estresse cíclico } \\
\cline { 2 - 7 } & $\mathbf{2 1}$ & $\mathbf{2 4}$ & $\mathbf{2 7}$ & $\mathbf{3 0}$ & $\mathbf{3 3}$ & $\mathbf{3 6}$ \\
\hline T MAX $\left({ }^{\circ} \mathrm{C}\right)$ & 21,79 & 26,19 & 28,52 & 31,66 & 34,40 & 37,45 \\
T MIN $\left({ }^{\circ} \mathbf{C}\right)$ & 18,18 & 22,91 & 26,04 & 29,08 & 32,92 & 35,60 \\
UR MAX (\%) & 70,05 & 86,75 & 79,42 & 80,92 & 82,57 & 64,49 \\
UR MIN (\%) & 54,80 & 63,35 & 64,40 & 67,64 & 64,64 & 52,24 \\
\hline
\end{tabular}

Como observado na Tabela 1, a variação média entre as temperaturas máxima e mínima durante o período experimental, para as temperaturas testadas, foi de $2,33^{\circ} \mathrm{C}$, ou seja, não houve grande variação da temperatura dentro dos limites préestabelecidos de programação da câmara. Para a variável de umidade relativa houve variação média de $16,38 \%$. Contudo, a umidade relativa, mesmo em condições de câmara, é de difícil controle, uma vez que é dependente de vários outros fatores. Tais fatores podem estar relacionados com o aumento no volume de fezes das aves e o aumento da perda de calor por evaporação (ofegação), contribuindo para o aumento desta variável.

Para a sala mantida em ambiente termoneutro, a temperatura foi de $21^{\circ} \mathrm{C} \pm$ $2^{\circ} \mathrm{C}$, durante todo o período experimental, com média de $62,42 \%$ para a umidade relativa.

Os resultados referentes ao desempenho de codornas poedeiras na fase de póspico de produção, submetidas ao estresse térmico, são apresentados na Tabela 2. Pode-se observar que não houve diferenças significativas para nenhuma das variáveis avaliadas, dentro da comparação entre 21 e $24^{\circ} \mathrm{C}$. Entretanto, dentro da comparação entre 21 e $27^{\circ} \mathrm{C}$, houve redução significativa no consumo de ração de $4,59 \%$ quando as aves foram submetidas à $27^{\circ} \mathrm{C}$. Já a exposição das aves à temperatura de $30^{\circ} \mathrm{C}$ proporcionou redução de $11,00 \%$ no consumo de ração, com consequências significativas sobre outras variáveis de desempenho, excetuando-se a percentagem de ovos viáveis e a conversão alimentar por massa de ovos. Dentro da comparação entre 
21 e $33^{\circ} \mathrm{C}$, verificou-se diminuição de $22,04 \%$ no consumo de ração e entre 21 e $36^{\circ} \mathrm{C}$ uma redução de $38,92 \%$.

Tabela 2. Consumo de ração (CR), Percentagem de postura (POST), percentagem de ovos viáveis (OVI), peso dos ovos (PO), massa de ovos (MO), conversão alimentar por dúzia $(\mathrm{CA} / \mathrm{dz})$ e por quilograma $(\mathrm{CA} / \mathrm{kg})$ de ovos produzidos de codornas japonesas submetidas a estresse por calor.

\begin{tabular}{cccccccc}
\hline $\begin{array}{c}\text { Temp } \\
\left({ }^{\circ} \mathbf{C}\right)\end{array}$ & $\begin{array}{c}\text { CR } \\
(\mathbf{g} / \mathbf{a v e} / \mathbf{d i a})\end{array}$ & $\begin{array}{c}\text { POST } \\
(\boldsymbol{\%})\end{array}$ & $\begin{array}{c}\text { OVI } \\
(\boldsymbol{\%})\end{array}$ & $\begin{array}{c}\text { PO } \\
(\mathbf{g})\end{array}$ & $\begin{array}{c}\text { MO } \\
(\mathbf{g} / \mathbf{a v e} / \mathbf{d i a})\end{array}$ & $\mathbf{C A} / \mathbf{d z}$ & $\mathbf{C A} / \mathbf{k g}$ \\
\hline $\mathbf{2 1}$ & 31,1 & 87,86 & 86,72 & 12,17 & 10,73 & 0,42 & 2,92 \\
$\mathbf{2 4}$ & 30,5 & 88,41 & 87,02 & 12,01 & 10,59 & 0,43 & 2,89 \\
$\mathbf{C V}(\boldsymbol{\%})$ & 4,22 & 2,14 & 2,98 & 1,91 & 2,44 & 5,04 & 4,61 \\
\hline $\mathbf{2 1}$ & $30,5 \mathrm{~A}$ & 87,84 & 86,83 & 12,16 & 10,68 & $0,42 \mathrm{~A}$ & $2,86 \mathrm{~A}$ \\
$\mathbf{2 7}$ & $29,1 \mathrm{~B}$ & 88,57 & 86,90 & 12,04 & 10,66 & $0,39 \mathrm{~B}$ & $2,73 \mathrm{~B}$ \\
$\mathbf{C V}(\boldsymbol{\%})$ & 3,32 & 2,82 & 3,27 & 1,72 & 3,53 & 3,88 & 3,86 \\
\hline $\mathbf{2 1}$ & $30,0 \mathrm{~A}$ & $87,82 \mathrm{~A}$ & 84,04 & $12,35 \mathrm{~A}$ & $10,85 \mathrm{~A}$ & $0,43 \mathrm{~A}$ & 2,77 \\
$\mathbf{3 0}$ & $26,7 \mathrm{~B}$ & $84,45 \mathrm{~B}$ & 85,86 & $11,85 \mathrm{~B}$ & $10,02 \mathrm{~B}$ & $0,37 \mathrm{~B}$ & 2,67 \\
$\mathbf{C V}(\boldsymbol{\%})$ & 4,14 & 3,53 & 3,64 & 1,71 & 4,15 & 5,72 & 6,16 \\
\hline $\mathbf{2 1}$ & $30,4 \mathrm{~A}$ & $87,93 \mathrm{~A}$ & $86,29 \mathrm{~A}$ & $12,33 \mathrm{~A}$ & $10,85 \mathrm{~A}$ & $0,42 \mathrm{~A}$ & $2,81 \mathrm{~A}$ \\
$\mathbf{3 3}$ & $23,7 \mathrm{~B}$ & $83,37 \mathrm{~B}$ & $80,78 \mathrm{~B}$ & $11,16 \mathrm{~B}$ & $9,31 \mathrm{~B}$ & $0,34 \mathrm{~B}$ & $2,53 \mathrm{~B}$ \\
$\mathbf{C V}(\boldsymbol{\%})$ & 4,51 & 4,36 & 4,75 & 2,07 & 5,58 & 4,96 & 5,53 \\
\hline $\mathbf{2 1}$ & $31,6 \mathrm{~A}$ & $83,56 \mathrm{~A}$ & $82,08 \mathrm{~A}$ & $11,26 \mathrm{~A}$ & $9,43 \mathrm{~A}$ & $0,46 \mathrm{~A}$ & $3,45 \mathrm{~A}$ \\
$\mathbf{3 6}$ & $19,3 \mathrm{~B}$ & $69,63 \mathrm{~B}$ & $64,35 \mathrm{~B}$ & $10,17 \mathrm{~B}$ & $7,08 \mathrm{~B}$ & $0,34 \mathrm{~B}$ & $2,81 \mathrm{~B}$ \\
$\mathbf{C V}(\boldsymbol{\%})$ & 8,84 & 10,79 & 12,06 & 5,73 & 11,52 & 6,93 & 10,33 \\
\hline
\end{tabular}

A,B Médias seguidas de letras maiúsculas distintas, na coluna, dentro de cada ciclo de temperatura avaliada, diferem entre si, pelo teste de Tukey $(p \leq 0,05)$.

Resultados semelhantes foram observados na literatura. Bordas e Minvelle (1997) também constataram diminuição no consumo de ração em aves submetidas ao estresse por calor $\left(35^{\circ} \mathrm{C}\right)$ quando comparadas às aves mantidas em temperatura termoneutra $\left(21^{\circ} \mathrm{C}\right)$. Andrade et al. (1977) trabalhando com poedeiras Leghorn, criadas em ambientes com temperaturas de $21^{\circ} \mathrm{C}$ e de $31^{\circ} \mathrm{C}$ verificaram que aves submetidas ao estresse por temperatura elevada reduziram a produção dos ovos, o peso dos ovos e o consumo alimentar. Özbey et al. (2006) avaliaram o efeito do estresse por calor em codornas japonesas, com exposição de temperaturas elevadas $\left(35^{\circ} \mathrm{C}\right)$ comparadas ao grupo controle (temperatura variável de 18 a $24^{\circ} \mathrm{C}$ ) durante a $2^{\mathrm{a}}$ até a $6^{\mathrm{a}}$ semana de vida das aves e constataram redução no consumo de ração, a partir da exposição na $4^{a}$ semana, com consequente diminuição no percentual e peso de carcaça. 
Sob circunstâncias de estresse por calor uma das primeiras respostas das aves é o decréscimo no consumo e, desta forma, as aves deixam de obter os nutrientes essenciais para a produção com consequentes perdas no potencial produtivo e na qualidade dos ovos.

Em relação ao percentual de postura, dentro da comparação entre 21 e $30^{\circ} \mathrm{C}$, houve redução no percentual de postura de $3,84 \%$ quando as aves foram submetidas à $30^{\circ} \mathrm{C}$. Quando as aves foram expostas a $33^{\circ} \mathrm{C}$, esta redução foi de $6,39 \%$ e aos $36^{\circ} \mathrm{C}$ foi de $16,67 \%$. Estes resultados provavelmente resultaram da diminuição no consumo de ração e, desta forma, pode reduzir a disponibilidade de nutrientes para a produção de ovos, o que está de acordo com Tinôco (1994). Resultados semelhantes foram obtidos por Jones et al. (1976), que utilizando poedeiras Leghorn brancas, submetidas às temperaturas de 24,5 e $35^{\circ} \mathrm{C}$, e rações de $2.671,2.853$ e $2.992 \mathrm{kcal} E M / \mathrm{kg}$, e concluíram que aves submetidas à temperatura de $35^{\circ} \mathrm{C}$ produziram menor número de ovos quando comparadas às aves submetidas à temperatura de $24,5^{\circ} \mathrm{C}$.

Não houve diferença significativa para percentual de ovos viáveis dentro das comparações entre temperatura termoneutra com 24,27 e $30^{\circ} \mathrm{C}$. No entanto, esta variável sofreu influência do aumento no número de ovos quebrados, trincados e com casca mole/fina, quando as aves foram expostas a condições de estresse severo $\left(33^{\circ} \mathrm{C}\right)$. Esta influência reduziu, significativamente, o percentual de ovos viáveis em $5,5 \%$, e aos $36^{\circ} \mathrm{C}$, esta redução foi ainda maior, chegando a $17,7 \%$. Os dados sobre o percentual de ovos viáveis são decorrentes, provavelmente, da alteração nos níveis de cálcio plasmático que seriam destinados à formação da casca dos ovos. Esta alteração pode ser resultado do processo de alcalose respiratória que ocorre quando a ave encontra-se sob condições de estresse térmico.

Analisando-se ainda a Tabela 2, verifica-se redução significativa no peso dos ovos a partir de $30^{\circ} \mathrm{C}$. Nesta temperatura a redução foi de $4,05 \%$. Quando as aves foram submetidas ao estresse de $33^{\circ} \mathrm{C}$, esta redução foi mais expressiva, sendo de $9,49 \%$. Aos $36^{\circ} \mathrm{C}$ houve redução de $9,68 \%$ no peso dos ovos.

Bordas \& Minvelle (1997) também constataram efeitos negativos do estresse por calor em pesquisa realizada com galinhas poedeiras de diferentes linhagens. Ao submeter aves a ambientes com $21^{\circ} \mathrm{C}$ e $35^{\circ} \mathrm{C}$, observaram que houve redução de $13 \%$ no número e $4 \%$ no peso dos ovos e que não houve diferença no desempenho com relação à linhagem das aves.

A massa dos ovos foi significativamente pior a partir dos $30^{\circ} \mathrm{C}$, com redução de $6,43 \%$ quando comparada à temperatura termoneutra. Quando submetidas a $33^{\circ} \mathrm{C}$, as 
aves apresentaram redução na massa de ovos de $14,19 \%$ e aos $36^{\circ} \mathrm{C}$, diminuição de $25,02 \%$. Estas reduções ocorreram em função da menor percentagem de postura e peso de ovos, observados nessas temperaturas. Por outro lado, Emery et al. (1984) estudando o efeito de temperaturas elevadas sobre o desempenho e qualidade dos ovos de poedeiras às 33 semanas de idade, em três câmaras bioclimáticas (temperatura constante de $23,9^{\circ} \mathrm{C}$; temperatura cíclica entre 15,6 e $37,7^{\circ} \mathrm{C}$ e temperatura cíclica entre 21,1 e $37,7^{\circ} \mathrm{C}$ ) relataram que não houve diferença estatística dentro das três situações de estudo, para produção e massa de ovos.

Para as conversões alimentares por dúzia e quilograma de ovos produzidos, observou-se melhores resultados a partir dos $27^{\circ} \mathrm{C}$, devido a grande redução no consumo de ração sem declínio proporcional da produção de ovos. Todavia, se o estresse pelo calor fosse prolongado por um maior período, provavelmente as aves iriam necessitar mobilizar reservas corporais para manutenção e, uma vez exauridas estas reservas, haveria redução na produção de ovos e piora nas demais características de desempenho.

Özbey et al. (2004) constataram efeitos negativos na avaliação de características de carcaça de codornas japonesas comparando grupos de aves na temperatura controle $\left(18-24^{\circ} \mathrm{C}\right) \mathrm{com}$ aves expostas em temperaturas elevadas $\left(35^{\circ} \mathrm{C}\right)$ em diferentes grupos de peso corporal (aves pesadas, $>27 \mathrm{~g}$ e leves, < 27g). Como resultados, foram encontradas reduções no peso vivo, consumo de ração, conversão alimentar e viabilidade, com efeitos mais acentuados no grupo de maior peso corporal, reforçando os efeitos negativos sob exposição a elevadas temperaturas, fato também ocorrido nesta pesquisa.

Os dados referentes à qualidade dos ovos são apresentados na Tabela 3 . Verifica-se que houve piora $(p<0,05)$ na gravidade específica a partir de $30^{\circ} \mathrm{C}$, quando comparada à temperatura termoneutra. A gravidade específica está intimamente relacionada à qualidade da casca dos ovos. Segundo Hamilton (1982), a gravidade específica aumenta à medida que a espessura da casca aumenta, ou seja, os valores são diretamente relacionados. 
Tabela 3. Gravidade específica (GE), resistência de casca à quebra (RES), espessura de casca (ESP), percentagem de casca (CASC), índice gema (IG), percentagem de gema (GEM), percentagem de albúmen (ALB) e unidade Haugh $(\mathrm{UH})$ de ovos de codornas japonesas submetidas a estresse por calor.

\begin{tabular}{ccccccccc}
\hline $\begin{array}{c}\text { Temp } \\
\left({ }^{\circ} \mathbf{C}\right)\end{array}$ & $\begin{array}{c}\mathbf{G E} \\
\left(\mathbf{m g} / \mathbf{c m}^{\mathbf{3}}\right)\end{array}$ & $\begin{array}{c}\mathbf{R E S} \\
\mathbf{( g )}\end{array}$ & $\begin{array}{c}\mathbf{E S P} \\
(\mathbf{m m})\end{array}$ & $\begin{array}{c}\mathbf{C A S C} \\
(\mathbf{\%})\end{array}$ & $\mathbf{I G}$ & $\begin{array}{c}\text { GEM } \\
(\boldsymbol{\%})\end{array}$ & $\begin{array}{c}\text { ALB } \\
(\boldsymbol{\%})\end{array}$ & $\mathbf{U H}$ \\
$\mathbf{2 1}$ & 1,074 & $1147,32 \mathrm{~A}$ & 0,31 & 7,85 & 0,49 & 29,74 & 62,41 & 88,31 \\
$\mathbf{2 4}$ & 1,074 & $1039,63 \mathrm{~B}$ & 0,31 & 7,92 & 0,49 & 29,97 & 62,10 & 89,67 \\
$\mathbf{C V}(\boldsymbol{\%})$ & 0,19 & 8,95 & 4,22 & 3,77 & 2,37 & 2,78 & 1,47 & 1,61 \\
\hline $\mathbf{2 1}$ & 1,073 & $1058,39 \mathrm{~A}$ & $0,31 \mathrm{~A}$ & $8,00 \mathrm{~A}$ & $0,50 \mathrm{~A}$ & 29,79 & 62,20 & $88,64 \mathrm{~A}$ \\
$\mathbf{2 7}$ & 1,071 & $871,65 \mathrm{~B}$ & $0,29 \mathrm{~B}$ & $7,70 \mathrm{~B}$ & $0,48 \mathrm{~B}$ & 30,09 & 62,21 & $86,08 \mathrm{~B}$ \\
$\mathbf{C V}(\boldsymbol{\%})$ & 0,19 & 10,83 & 3,32 & 3,02 & 2,96 & 1,30 & 0,68 & 2,37 \\
\hline $\mathbf{2 1}$ & $1,074 \mathrm{~A}$ & $1101,44 \mathrm{~A}$ & $0,30 \mathrm{~A}$ & 7,92 & $0,50 \mathrm{~A}$ & 30,35 & 61,72 & $90,89 \mathrm{~A}$ \\
$\mathbf{3 0}$ & $1,070 \mathrm{~B}$ & $961,61 \mathrm{~B}$ & $0,27 \mathrm{~B}$ & 7,77 & $0,48 \mathrm{~B}$ & 30,13 & 62,09 & $88,52 \mathrm{~B}$ \\
$\mathbf{C V}(\boldsymbol{\%})$ & 0,29 & 10,14 & 4,14 & 3,70 & 2,70 & 2,74 & 1,27 & 2,30 \\
\hline $\mathbf{2 1}$ & $1,074 \mathrm{~A}$ & $1013,58 \mathrm{~A}$ & $0,30 \mathrm{~A}$ & 7,95 & $0,49 \mathrm{~A}$ & 30,36 & 61,69 & $90,53 \mathrm{~A}$ \\
$\mathbf{3 3}$ & $1,070 \mathrm{~B}$ & $881,41 \mathrm{~B}$ & $0,24 \mathrm{~B}$ & 7,72 & $0,47 \mathrm{~B}$ & 29,69 & 62,76 & $87,13 \mathrm{~B}$ \\
$\mathbf{C V}(\boldsymbol{\%})$ & 0,24 & 13,64 & 4,51 & 4,00 & 1,50 & 3,56 & 1,98 & 2,00 \\
\hline $\mathbf{2 1}$ & $1,070 \mathrm{~A}$ & 997,37 & $0,32 \mathrm{~A}$ & 7,67 & $0,47 \mathrm{~A}$ & $30,29 \mathrm{~A}$ & $62,03 \mathrm{~B}$ & 90,15 \\
$\mathbf{3 6}$ & $1,067 \mathrm{~B}$ & 964,73 & $0,19 \mathrm{~B}$ & 7,69 & $0,43 \mathrm{~B}$ & $28,84 \mathrm{~B}$ & $63,46 \mathrm{~A}$ & 88,30 \\
$\mathbf{C V}(\boldsymbol{\%})$ & 0,23 & 10,98 & 8,84 & 3,09 & 2,80 & 4,18 & 1,92 & 2,75 \\
\hline A,B
\end{tabular}

A,B Médias seguidas de letras maiúsculas distintas, na coluna, dentro de cada ciclo de temperatura avaliada, diferem entre si, pelo teste de Tukey $(p \leq 0,05)$.

Existe elevada correlação positiva entre gravidade específica, espessura e percentual de casca com a resistência da casca à quebra. Segundo Molino et al. (2009), a melhor forma de avaliar a qualidade da casca é a avaliação de sua resistência à quebra. A relação entre os fatores citados acima também pode ser constatada nesta pesquisa, uma vez que a elevação da temperatura acima dos $21^{\circ} \mathrm{C}$ reduziu, significativamente, a resistência de casca à quebra (Tabela 3). A partir dos $27^{\circ} \mathrm{C}$ a espessura da casca foi reduzida, e a partir dos $30^{\circ} \mathrm{C}$ observou-se diminuição da gravidade específica. O percentual de casca sofreu influência negativa apenas aos $27^{\circ} \mathrm{C}$. Entretanto, apesar de tais resultados a percentagem de ovos viáveis para comercialização sofreu influência efetivamente negativa apenas a partir dos $33^{\circ} \mathrm{C}$, ou seja, a piora na qualidade da casca não foi suficiente para reduzir a percentagem de ovos viáveis para a comercialização até a temperatura de $30^{\circ} \mathrm{C}$. 
Os percentuais de redução para a resistência da casca à quebra foram de 9,39\%, 17,64\%; 12,69\% e 13,04\%, respectivamente, para as temperaturas de 24,27 , 30 e $33^{\circ} \mathrm{C}$ (Tabela 3). Quando as aves foram submetidas ao estresse de $36^{\circ} \mathrm{C}$ não observou-se diferenças significativas, tais resultados podem ser explicados devido a um erro de amostragem dos ovos.

Os resultados de espessura de casca sofreram redução significativa a partir de $27^{\circ} \mathrm{C}$, sendo observadas reduções médias de 4,59\%, $11,00 \%, 22,04 \%$ e 38,92\%, respectivamente, para as temperaturas de $27,30,33$ e $36^{\circ} \mathrm{C}$. Tais resultados justificam o aumento de ovos com casca fina e com presença de rachaduras, reforçando os dados encontrados para diminuição do percentual de ovos viáveis com a elevação da temperatura ambiente.

Dados semelhantes ao do presente estudo foram observados por FrancoJimenez et al. (2007), que trabalharam com linhagens genéticas de poedeiras comerciais (Hy-Line Brown, W-36 e W-98) e as submeteram ao estresse por calor a $35^{\circ} \mathrm{C}$, durante duas semanas. Os autores encontraram diferenças significativas na produção de ovos, consumo de ração, espessura da casca e gravidade específica. Todos os parâmetros foram reduzidos em $3 \%$ ou mais em relação às aves mantidas em temperatura ambiente $\left(22^{\circ} \mathrm{C}\right)$.

Mashaly et al. (2004) submeteram aves poedeiras de 31 semanas a três tratamentos em uma câmara bioclimática, com temperaturas cíclicas e sob condições de estresse térmico constante a $35^{\circ} \mathrm{C}$ com $50 \%$ de UR. Como resposta, os autores verificaram que o ganho de peso das aves e o consumo de ração foram reduzidos nas condições de estresse, bem como o peso dos ovos, espessura e peso da casca e a gravidade específica.

A redução da qualidade interna do ovo se reflete, principalmente, no índice gema e na unidade Haugh. Para a condição ambiental de estresse térmico constatou-se redução significativa de $4,0 \%$ no índice gema e de $2,89 \%$ na unidade Haugh com o aumento da temperatura para $27^{\circ} \mathrm{C}$, comparado aos dados encontrados em condições de termoneutralidade. A elevação da temperatura para 30,33 e $36^{\circ} \mathrm{C}$, reduziu em 4,0 ; 4,08 e $8,51 \%$ o índice gema e em 8,75; 8,61 e 8,73\% a unidade Haugh, respectivamente. Estes dados demonstram que temperaturas elevadas interferem negativamente nestes parâmetros, considerados como os melhores indicativos para avaliação de qualidade interna dos ovos. Resultados semelhantes foram encontrados por Kirunda et al. (2001) trabalhando com poedeiras, que verificaram diminuição dos 
valores de unidade Haugh em relação aos valores observados durante duas semanas, antes da exposição das aves ao estresse por calor de $34^{\circ} \mathrm{C}$.

Barbosa Filho (2006) avaliou a qualidade dos ovos e bem-estar de duas linhagens de poedeiras (Hy-Line W-36 e Hy-line Brown), submetidas a duas condições ambientais $\left(26^{\circ} \mathrm{C}\right.$ e $60 \%$ UR ou $35^{\circ} \mathrm{C}$ e $70 \%$ UR) com dois sistemas de criação (gaiolas ou cama) e também verificou redução significativa na unidade Haugh dos ovos produzidos por poedeiras sob estresse por calor, principalmente em aves alojadas em gaiolas.

Houve diferença significativa para percentual de gema e albúmen apenas quando as aves foram submetidas a $36^{\circ} \mathrm{C}$, situação na qual constatou-se redução na percentagem de gema e consequente elevação proporcional de albúmen comparativamente à temperatura termoneutra.

Os efeitos do estresse pelo calor em codornas japonesas já foram relatados por Araújo et al. (2007) e estes autores observaram que, em codornas com 63 dias de idade estressadas pelo calor, o uso de cromo orgânico em comparação ao grupo sem suplementação, aumentou o consumo de alimento e a taxa de postura de ovos comercializáveis.

O conteúdo de sólidos totais no ovo inteiro é influenciado pela proporção de gema e albúmen e pelos seus conteúdos de sólidos. A proporção de gema e albúmen varia amplamente com o tamanho do ovo, assim, em ovos pequenos, há menor quantidade de gema que em ovos grandes. O albúmen é constituído principalmente de água (88\%), sendo sua quantidade de sólidos totais de $12 \%$. O conteúdo de sólidos totais da gema é de aproximadamente 50\% (Ahn et al., 1997; Tharrington et al., 1999; Scott \& Silversides, 2000). Nesta pesquisa, apesar da diferença significativa observada para percentual de gema e albúmen dentro da comparação entre 21 e $36^{\circ} \mathrm{C}$ (Tabela 3) não foi constatado influência da temperatura no percentual de sólidos (Tabela 4), contrapondo a hipótese destes autores. 
Tabela 4. Percentagem de sólidos do albúmen e da gema para a temperatura termoneutra $\left(21^{\circ} \mathrm{C}\right)$ e para as temperaturas testes $\left(24,27,30,33\right.$ e $\left.36^{\circ} \mathrm{C}\right)$.

\begin{tabular}{ccc}
\hline Temperatura $\left({ }^{\mathbf{0}} \mathbf{C}\right)$ & Sólidos de Albúmen $(\boldsymbol{\%})$ & Sólidos de Gema (\%) \\
\hline $\mathbf{2 1}$ & 14,24 & 58,63 \\
$\mathbf{2 4}$ & 16,88 & 63,06 \\
$\mathbf{C V}(\boldsymbol{\%})$ & 25,4 & 13,24 \\
\hline $\mathbf{2 1}$ & 12,87 & 58,74 \\
$\mathbf{2 7}$ & 14,34 & 57,54 \\
$\mathbf{C V}(\boldsymbol{\%})$ & 17,02 & 8,54 \\
$\mathbf{2 1}$ & 14,95 & 68,24 \\
$\mathbf{3 0}$ & 18,87 & 64,02 \\
$\mathbf{C V}(\boldsymbol{\%})$ & 15,98 & 12,90 \\
\hline $\mathbf{2 1}$ & 13,51 & 54,47 \\
$\mathbf{3 3}$ & 13,00 & 53,50 \\
$\mathbf{C V}(\boldsymbol{\%})$ & 15,67 & 13,59 \\
$\mathbf{2 1}$ & 11,43 & 61,97 \\
$\mathbf{3 6}$ & 11,81 & 58,96 \\
$\mathbf{C V}(\boldsymbol{\%})$ & 4,07 & 9,19 \\
\hline
\end{tabular}

\section{CONCLUSÕES}

Temperatura ambiente contínua a partir de $30^{\circ} \mathrm{C}$ reduz o consumo de ração, a produção, o peso e a massa dos ovos. A qualidade interna e externa dos ovos é afetada já aos $27^{\circ} \mathrm{C}$. Desta forma, aspectos como o ambiente e o bem-estar devem ser considerados, pois afetam a produção e qualidade dos ovos de codornas japonesas. Os resultados nos permitem concluir que a temperatura crítica superior da zona de termoneutralidade para codornas japonesas é de $27^{\circ} \mathrm{C}$, a qual não deve ser excedida nas instalações de criação para evitar prejuízos na qualidade dos ovos.

\section{REFERÊNCIAS}

Ahn, D.U.; Kim, S.M.; Shu, H. Effect of egg size and strain and age of hens on the solids content of chicken eggs. Poultry Science, 1997, 76: 914-919. 
Andrade, A. N.; Rogler, J.C.; Featherston, W. R.; Alliston, C. W. Interrelationship between diet and elevate temperatures (cyclic and constant) on egg production and shell quality. Poultry Science, 1977, 56(4): 1178-1118.

Araújo, M. S; Barreto, S. L. T; Donzele, J. L; Oliveira, R. F.M.; Umigi, R. T.; Oliveira, W. P.; Balbino, E. M.; Assis, A. P.; Maia, G. V. C. Níveis de cromo orgânico na dieta de codornas japonesas mantidas em estresse por calor na fase de postura. Revista Brasileira de Zootecnia, 2007, 36(3): 584-588.

Barbosa Filho, J. A. D. Egg quality in layers housed in different production systems and submitted to two environmental conditions. Revista Brasileira de Ciência Avícola, 2006, 8 (1): 23-28.

Bordas, A.; Minvelle, F. Responsé à la chaleur de poules pondeuses issues de lignées sélectionnéss pour une faible $\left(R^{-}\right)$ou forte $\left(R^{+}\right)$consomation alimentaire résiduelle. Genetics, Selection, Evolution, 1997, 29 (3): 279-290.

Darre, M. J.; Harrison, P. C. Heart rate, blood pressure, cardiac output and total peripheral resistance of single comb White Leghorn hens during an acute exposure to $35^{\circ} \mathrm{C}$ ambient temperature. Poultry Science, Stanford, 1987, 66: 541-547.

Emery, D. A.; Vhora, R.; Ernst, R.A. The effect of cyclic and constant ambient temperatures on feed consumption, egg production, egg weight, and shell thickness of hens. Poultry Science, 1984, 63: 2027-2035.

Ferreira, D. F. Programa Sisvar.exe. Sistema de Análises de Variância. Versão 3.04, 1998.

Franco-Jimenez D. J.; Scheideler S. E.; Kittok R.J.; Brown-Brandl T.M.; Robeson L.R.; Taira H., Beck M. M. Differential effects of heat stresss in three strains of laying hens. The Journal of Applied Poultry Research, 2007, 16 (4): 628-634.

Freeman, B. M. Physiological responses of the adult fowl to environmental temperature. World Poultry Science Journal, London, 1965, 21: 140-145. 
Hamilton, R. M. G. Methods and factors that affect measurement of egg shell quality. Poultry Science, Champaign, 1982, 61: 2002-2039.

Jones, J. E; Hughes, B. L.; Barnett, B. D. Effect of choching dietary energy levels and environmental temperatures on feed consumption and eggs production of sinle comb white Leghorns. Poultry Science, 1976, 55 (1): 274-277.

Kirunda, D. F.; Scheideler, S. E.; McKee, S. R. The efficacy of vitamin E (DL-alphatocopheryl acetate) supplementation in hen diets to alleviate egg quality deterioration associated with high temperature exposure. Poultry Science, 2001, 80: 1378-1383.

Macari M, Furlan RL, Gonzales E. Fisiologia aviária aplicada a frangos de corte. Jaboticabal (SP): FUNEP/UNESP; 1994.

Mashaly, M.M.; Hendrics, G.L.; Kalama, M.A. et al. Effect of heat stress on production parameters and imune response of comercial laying hens. Poultry Science, 2004, 83: 889-894.

Molino, A. B.; Garcia, E. A.; Gonçalves, H. C.; Pelícia, K.; Berto, D. A.; Silva, A. P. Avaliação de medidas de qualidade da casca dos ovos de poedeiras comerciais. In: VII CONGRESSO DE PRODUÇÃO, COMERCIALIZAÇÃO E CONSUMO DE OVOS, 2009, São Pedro, APA, 2009, Anais... p. 164-167.

Murakami, A. E.; Ariki, J. Produção de codornas japonesas. Jaboticabal: FUNEP, 1998. 79 p.

NRC - National Research Council. Nutrient requirements of poultry. Washington: Natl. Acad. Press. 9 ed., 1994; 156 p.

Oliveira, B. L. Manejo racional e produtividade das codornas (Coturnix coturnix japonica). In: SIMPÓSIO INTERNACIONAL DE COTURNICULTURA, 01, 2002, Lavras. Anais... Lavras: UFLA, 2002, p. 77-84. 
Özbey, O.; Erisir, Z.; Aysöndü, M. H.; Özmen, Ö. The effect of high temperatures on breeding and survival of japanese quails that are bred under different temperatures. International Journal of Poultry Science, 2004, 3 (7): 463-467.

Özbey, O.; Yildiz, N.; Esen, F. The Effects of High Temperature on Breeding Characteristics and the Living Strength of the Japanese Quails (Coturnix Coturnix Japonica). International Journal of Poultry Science, 2006, 5 (1): 56-59.

Poyraz, O.; Ina M.; Akcan, A. The effect of high enviromental temperature on layer hens. I. Some production traits. Journal of Veterinary Faculty of Ankara University, 1991, 38: 24-39.

Rodrigues, E. Fisiologia da homeotermia. Disponível em: http://www.ufrrj/institutos/it/dau/profs/edmundo > Acesso em: 01 de novembro de 2006.

Scott, T.A.; Silversides, F.G. The effect of storage and strain of hen on egg quality. Poultry Science, 2000, 79: 1725- 1729.

Silva, I. J. O.; Sevegnani, K.B. Ambiência e instalações na avicultura de postura. In: SILVA, I.J.O. (ed.) Ambiência na produção de aves em clima tropical. Jaboticabal: SBEA, 2001, 2: 150-214.

Staldeman, W. J.; Cotterill, O. J. Egg science and Technology. Food Products Prees,

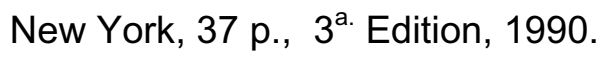

Tharrington, J. B.; Curtis, P. A.; Jones, F. T.; Anderson, K. E. Comparison of physical quality and composition of eggs from historic strains of single comb white leghorn chickens. Poultry Science, 1999, 78: 591-594.

Tinôco, I. F. F. Resfriamento adiabático evaporativo no controle térmico de galpões avícolas. In: CONFERÊNCIA APINCO DE CIÊNCIA E TECNOLOGIA, 1994, Campinas. Anais... Campinas: Associação Brasileira dos Produtores de Pintos de Corte, 1994, p.119. 
CAPÍTULO 3 


\title{
DESEMPENHO E QUALIDADE DE OVOS DE CODORNAS JAPONESAS SOB ESTRESSE CÍCLICO PELO CALOR
}

\begin{abstract}
RESUMO
Com o objetivo de avaliar o efeito da temperatura cíclica sobre o desempenho e a qualidade de ovos de codornas japonesas foi realizado um experimento utilizando-se 480 aves na fase de pós-pico de produção. As aves foram alojadas em uma câmara bioclimática com controle automático de temperatura, contendo duas baterias compostas de cinco andares e dez gaiolas, com capacidade para 24 aves cada gaiola, divididas em duas salas de temperatura; 240 aves na temperatura controle $\left(21^{\circ} \mathrm{C}\right) \mathrm{e}$ 240 aves submetidas em ambiente de estresse cíclico pelo calor, na qual, eram expostas durante 10 horas, diariamente, na temperatura a ser testada. Após este procedimento, os aparelhos de aquecimento eram desligados. As temperaturas pesquisadas foram: $24,27,30,33$ e $36^{\circ} \mathrm{C}$, comparadas aos dados das aves mantidas na sala de temperatura termoneutra $\left(21^{\circ} \mathrm{C}\right)$. O período experimental foi dividido em cinco ciclos de 14 dias (um ciclo para cada temperatura). No final de cada ciclo experimental foi avaliado o desempenho e a qualidade dos ovos. Para todos os tratamentos, as rações foram isonutritivas e isocalóricas. Para a avaliação do desempenho e da qualidade dos ovos utilizou-se um delineamento inteiramente casualizado com dois tratamentos (temperatura termoneutra e temperatura teste) e dez repetições de 24 aves por parcela. Elevações cíclicas na temperatura ambiente afetam negativamente o desempenho e a qualidade dos ovos a partir de $27^{\circ} \mathrm{C}$, comprovando o consequente efeito do estresse térmico no metabolismo e no equilíbrio térmico corporal das aves.
\end{abstract}

Palavras-chave: Coturnix coturnix japonica, estresse por calor, pós-pico de produção, produção de ovos, temperatura ambiente. 


\title{
PERFORMANCE AND QUALITY OF EGGS` JAPANESE QUAILS UNDER CYCLIC HEAT STRESS
}

\begin{abstract}
In order to evaluate the effect of cyclic temperature on performance and egg quality of Japanese quails was conducted an experiment using 480 birds in the postpeak production. The birds were housed in a climate chamber with automatic temperature control, with two batteries composed of five floors and ten cages for up to 24 birds in each cage, divided into two rooms temperature, 240 birds in the control temperature $\left(21^{\circ} \mathrm{C}\right)$ and 240 birds were in an environment of cyclic stress, in which they were exposed for 8 hours the temperature to be tested. After this procedure, the heaters were turned off. The temperatures studied were $24,27,30,33$ and $36^{\circ} \mathrm{C}$, compared to data from birds kept at thermoneutral room temperature $\left(21^{\circ} \mathrm{C}\right)$. The experimental was divided into five cycles of 14 days (one cycle for each temperature). At the end of each experimental cycle was evaluated performance and egg quality. For all treatments, the diets were isocaloric and isonutritives. For the evaluation of performance and quality of eggs used a completely randomized design with two treatments (temperature and thermoneutral temperature test) and ten replicates of 24 birds per plot. Cyclical highs in temperature adversely affect the parameters and egg quality proving the consequent effect of heat stress on metabolism and body heat balance of birds. From $27^{\circ} \mathrm{C}$ exposure to study conditions, the birds have provided evidence of heat stress.
\end{abstract}

Keywords: Coturnix coturnix japonica, eggs' production, heat stress, post-peak production, temperature 


\section{INTRODUÇÃO}

O avanço tecnológico permitiu melhoria dos principais índices técnicos de produção avícola, entretanto, as exigências quanto à implantação destas estão relacionadas cada vez mais à qualidade do produto final. Estas exigências pela qualidade são cada vez maiores nos mercados nacional e internacional, o que se evidencia pela crescente preocupação com o bem-estar e a segurança animal, além de práticas de manejo adotadas na cadeia de produção de carne e ovos (MAZZUCO, 2006).

Assim como a avicultura de corte, a avicultura de postura vem atingindo novos mercados com a abertura de exportação de ovos de galinhas, principalmente para os países árabes, o que pode representar também a possibilidade de exportação de ovos de codornas.

Para atingir melhores resultados econômico-produtivos, a moderna avicultura precisa considerar não só os aspectos genéticos, nutricionais e sanitários, como também os aspectos ambientais (BAÊTA, 1997). De acordo com Tinôco (1995), dentre os fatores ambientais, os fatores térmicos representados pela temperatura do ar, umidade, radiação térmica e movimentação do ar exercem a maior influência, afetando diretamente as aves, pois comprometem a manutenção da própria homeotermia.

Durante um longo período o conforto térmico ambiental foi considerado um problema secundário, tanto do ponto de vista etológico quanto produtivo. Presumia-se que o desconforto térmico seria resolvido com o uso de condicionamento artificial, sem se considerar os custos e os problemas relacionados à implantação de um sistema climatizado. Porém, segundo Silva (1999), a preocupação com o conforto térmico animal tem crescido notoriamente na última década, principalmente, quando associada às respostas fisiológicas e aos respectivos índices produtivos.

Como todos os homeotermos, as aves possuem temperatura corpórea interna constante. De acordo com os princípios da termodinâmica, isso significa que estes animais estão em troca térmica contínua com o ambiente. Porém, este processo só é eficiente quando a temperatura ambiental estiver dentro dos limites de termoneutralidade (Hannas, 1999).

Em situações de temperaturas elevadas, além do aumento da temperatura retal das aves, ocorre também aumento da frequência respiratória, com consequente efeito no metabolismo, para estimular a perda evaporativa de calor (ofegação) e para manter o equilíbrio térmico corporal (Silva et al., 2001; Macari et al., 2004). Paralelamente ao 
aumento da temperatura corporal e da frequência respiratória, processos fisiológicos são ativados com a finalidade de aumentar a dissipação de calor e reduzir a produção metabólica de calor para manutenção da homeotermia corporal (Yahav et al., 2005). Bottje \& Harrison (1985) e Furlan et al. (1999) também associaram o aumento da taxa respiratória ao resfriamento corporal por evaporação, ou seja, em situações de hipertermia, as aves aumentam a taxa respiratória para elevar a evaporação e, consequentemente, resfriar o corpo.

Portanto, o estresse por calor constitui fator responsável por grandes perdas na indústria avícola. Assim, a temperatura ambiente e umidade são fatores que devem ser considerados, uma vez que o desequilíbrio destes produz sérias alterações no sistema fisiológico do animal, podendo diminuir a rentabilidade, devido à redução na ingestão de alimentos, comprometendo, dessa forma, o desempenho das aves e com consequente redução na produção de carne e ovos, além de comprometimento da qualidade. Nesse sentido, este estudo objetivou avaliar o efeito de temperaturas cíclicas sobre as características de desempenho e qualidade de ovos de codornas japonesas, alojadas em câmara bioclimática.

\section{MATERIAL E MÉTODOS}

Este estudo foi conduzido na Unesp, Faculdade de Medicina Veterinária e Zootecnia/Botucatu/SP, na câmara climática, durante os meses de janeiro a março de 2009. Foram utilizadas 480 codornas japonesas (Coturnix coturnix japonica) na fase de pós-pico de produção (36 semanas de idade), alojadas em câmara bioclimática contendo duas salas de dimensões de $4,30 \mathrm{~m}$ de comprimento por 4,5m de largura e $2,60 \mathrm{~m}$ de altura, cada. Cada sala possui uma bateria composta de cinco andares com 10 gaiolas de arame galvanizado. As gaiolas com dimensões de $100 \mathrm{~cm}$ de comprimento, $34 \mathrm{~cm}$ de profundidade e $16 \mathrm{~cm}$ de altura possuem seis compartimentos internos, cada um com capacidade para quatro aves, permitindo a acomodação de 24 aves por gaiola e uma densidade de $141,67 \mathrm{~cm}^{2} /$ ave.

Utilizou-se o delineamento experimental inteiramente casualizado, constituído de dois tratamentos (temperatura termoneutra e temperatura teste) com dez repetições de 24 aves por parcela. O período experimental total foi dividido em cinco ciclos de 14 dias (um ciclo para cada temperatura teste). Do total de aves utilizadas, 240 codornas constituíram o grupo controle $\left(21^{\circ} \mathrm{C}\right)$ e as 240 aves restantes, o grupo experimental, que foi submetido às temperaturas cíclicas de $24,27,30,33$ e $36^{\circ} \mathrm{C}$ (aves expostas, 
diariamente, durante 10 horas a cada ciclo de temperatura a ser testada). Os resultados obtidos no grupo experimental, para cada temperatura teste, foram comparados aos dados observados no grupo controle $\left(21^{\circ} \mathrm{C}\right)$, com as aves possuindo a mesma idade.

O programa de luz adotado foi de 17 horas de luz diárias. Durante todo o período experimental, as aves foram submetidas a idêntico manejo alimentar, sendo fornecidas água e ração à vontade. $\mathrm{O}$ arraçoamento foi realizado duas vezes ao dia com dietas isonutritivas, compostas por milho e farelo de soja, fornecendo $2.800 \mathrm{kcal}$ de EM/kg de ração, $20 \%$ de proteína bruta, $3,2 \%$ de cálcio, $0,35 \%$ de fósforo disponível, $0,45 \%$ de metionina, $0,76 \%$ de metionina + cistina e $1,07 \%$ de lisina, de acordo com as exigências nutricionais propostas pelo NRC (1994).

$O$ aquecimento das salas foi realizado com o auxílio de três aquecedores elétricos acoplados a um termostato e o resfriamento através da utilização de aparelhos de ar condicionado, dotados de controle automático de temperatura. Os valores de temperatura e umidade relativa do ar (máxima e mínima) foram obtidos através de um termo-higrômetro e anotados diariamente em formulários próprios.

As características de desempenho avaliadas foram: consumo de ração, percentagem de postura, percentagem de ovos viáveis, peso médio dos ovos, massa de ovos, conversão alimentar por dúzia e por quilograma de ovos produzidos. Diariamente, foram anotados o número de ovos inteiros e quebrados para posterior cálculo da percentagem de postura e de ovos viáveis.

O consumo de ração por ave foi determinado semanalmente através da diferença entre a quantidade fornecida diariamente e as sobras existentes no final de cada período de sete dias. O resultado foi dividido pelo número médio de aves de cada parcela e expresso em gramas por ave por dia.

A percentagem de postura foi obtida dividindo-se o número total de ovos postos por gaiola na semana pelo número médio de aves multiplicado por sete, e o resultado multiplicado por 100. O percentual de ovos viáveis foi obtido pelo número total de ovos viáveis produzidos na semana, dividido pelo número total de ovos produzidos e o resultado multiplicado por 100 . Os ovos viáveis foram pesados semanalmente. O peso médio foi obtido dividindo-se o peso total dos ovos das gaiolas pelo número de ovos das mesmas e o resultado expresso em gramas.

A massa de ovos produzida foi obtida multiplicando-se a percentagem de ovos postos no período pelo peso dos ovos postos no mesmo período, o valor obtido foi expresso em gramas/ave/dia. 
A conversão alimentar por dúzia de ovos produzidos foi mensurada semanalmente, dividindo-se o peso total da ração consumida na parcela, expresso em quilogramas, pelo respectivo número de dúzias de ovos produzidos na semana. A conversão alimentar por quilograma de ovos produzidos foi mensurada a cada semana, dividindo-se o peso total da ração consumida, expressa em quilogramas, pelo peso dos ovos postos no período, também expresso em quilogramas.

A análise da qualidade dos ovos foi efetuada, para cada temperatura, ao final dos 14 dias de coleta de dados, durante três dias consecutivos. A cada dia foi coletada uma amostra de dois ovos por parcela, perfazendo um total de 60 ovos por temperatura avaliada. No último dia de cada ciclo foram coletadas quatro amostras de ovos para análise do conteúdo de sólidos totais.

As características de qualidade dos ovos avaliadas foram gravidade especifica, percentagens de gema, albúmen e casca, índice gema, espessura da casca, resistência da casca à quebra e unidade Haugh. A gravidade específica dos ovos foi calculada segundo metodologia descrita por Staldelman \& Cotterill (1990).

A percentagem de gema, albúmen e casca foram obtidas dividindo-se seus respectivos pesos pelo peso do ovo e o resultado multiplicado por 100. O índice gema foi calculado dividindo-se a altura da gema pelo diâmetro da mesma, sendo que a altura da gema foi obtida através do uso de um micrômetro, sendo mensurada na região mediana e o valor expresso em milímetros.

A espessura da casca foi mensurada através da utilização de um paquímetro digital, tomando-se três medidas na zona equatorial do ovo, após as cascas serem secas em estufa durante três dias, sob temperatura de $60^{\circ} \mathrm{C}$. As espessuras foram expressas em milímetros.

A resistência da casca à quebra foi determinada na região equatorial do ovo com o auxílio de um texturômetro TA.XT Plus - Texture Analyser utilizando-se sonda de ruptura de $2 \mathrm{~mm}$, velocidade de pré- teste de $2 \mathrm{~mm} /$ segundo; velocidade do teste 1,0 $\mathrm{mm} /$ segundo e velocidade pós-teste de $40 \mathrm{~mm} / \mathrm{segundo}$, a qual registrou a força necessária para romper a casca e o resultado expresso em gramas.

Para o cálculo da unidade Haugh, foi determinada inicialmente a altura do albúmen, com o auxílio de um paquímetro digital sendo efetuado, posteriomente, o cálculo empregando-se a fórmula descrita por Stadelman \& Cotterill (1990): UH = 100 $\log \left(H+7,57-1,7 \mathrm{~W}^{0,37}\right)$, sendo, $H=$ altura do albúmen $(\mathrm{mm}) ; \mathrm{W}=$ peso do ovo $(\mathrm{g})$; $7,57=$ fator de correção para altura do albúmen; $1,7=$ fator de correção para peso do ovo. 
Os teores de sólidos totais foram determinados separadamente no albúmen e na gema. Foram pesados um pool de gema e um pool de albúmen de quatro ovos em cadinhos de porcelana previamente secos em estufa de $105^{\circ} \mathrm{C}$, para a retirada da umidade, durante 48 horas. Os cálculos utilizados para a determinação da umidade e dos sólidos totais foram: Teor de umidade $(\mathrm{g} / 100 \mathrm{~g})=[(\mathrm{A}-\mathrm{B}) / \mathrm{C}] \times 100$, sendo: $\mathrm{A}=$ peso do recipiente e amostra; $B=$ peso do recipiente e amostra após secagem e $C=$ peso da amostra. Teor de sólidos totais $(\mathrm{g} / 100 \mathrm{~g})=100$ - teor de umidade $(\mathrm{g} / 100 \mathrm{~g})$

A análise estatística dos resultados foi realizada com o auxílio do programa estatístico SISVAR, de acordo com Ferreira (1998). Os resultados foram avaliados através da análise de variância e as médias foram comparadas pelo teste de Tukey a $5 \%$ de significância.

\section{RESULTADOS E DISCUSSÃO}

As médias de temperatura máxima foram obtidas durante as 10 horas diárias de exposição às temperaturas testadas e as médias de temperatura mínima foram obtidas durante a madrugada, quando a câmara encontrava-se desligada. As médias de máxima e mínima (temperatura e umidade relativa do ar) durante cada ciclo foram apresentadas na Tabela 1.

Tabela 1. Médias de temperaturas máxima ( $T M A X)$ e mínima ( $T$ MIN) e umidade relativa do ar máxima (UR MAX) e mínima (UR MIN) nas câmaras climáticas.

\begin{tabular}{lcccccc}
\hline & Termoneutra & \multicolumn{5}{c}{ Estresse cíclico } \\
\cline { 2 - 7 } & $\mathbf{2 1}$ & $\mathbf{2 4}$ & $\mathbf{2 7}$ & $\mathbf{3 0}$ & $\mathbf{3 3}$ & $\mathbf{3 6}$ \\
\hline T MAX $\left({ }^{\circ} \mathbf{C}\right)$ & 24,32 & 26,11 & 28,12 & 30,68 & 34,40 & 36,61 \\
T MIN $\left({ }^{\circ} \mathbf{C}\right)$ & 20,76 & 22,91 & 25,40 & 26,62 & 28,30 & 27,83 \\
UR MAX (\%) & 86,34 & 86,75 & 88,00 & 88,00 & 87,57 & 79,57 \\
UR MIN (\%) & 65,40 & 73,35 & 86,10 & 81,86 & 68,07 & 63,28 \\
\hline
\end{tabular}

Analisando-se a Tabela 1, observa-se que média de variação entre as temperaturas máxima e mínima durante o período experimental, para as temperaturas testadas, foi de $4,97^{\circ} \mathrm{C}$. Para a variável de umidade relativa houve uma média de variação de 11,56\%. Contudo, a umidade relativa, mesmo em condições de câmara, é de difícil controle, uma vez que é dependente de vários outros fatores. Tais fatores podem estar relacionados com o aumento no volume de fezes das aves e o aumento 
da perda de calor por evaporação (ofegação), contribuindo para o aumento desta variável.

Para a sala mantida em ambiente termoneutro, a temperatura foi de $21^{\circ} \mathrm{C} \pm 2^{\circ} \mathrm{C}$, com média de $53,64 \%$ para a umidade relativa durante todo o período experimental.

Os resultados de desempenho de codornas japonesas na fase de pós-pico de produção submetidos a estresse cíclico de temperatura são apresentados na Tabela 2.

Tabela 2. Consumo de ração (CR), Percentagem de postura (POST), percentagem de ovos viáveis (OVI), peso dos ovos (PO), massa de ovos (MO), conversão alimentar por dúzia (CA/dz) e por quilograma $(\mathrm{CA} / \mathrm{kg})$ de ovos produzidos de codornas japonesas submetidas a estresse cíclico por calor.

\begin{tabular}{cccccccc}
\hline $\begin{array}{c}\text { Temp } \\
\left({ }^{\circ} \mathbf{C}\right)\end{array}$ & $\begin{array}{c}\text { CR } \\
(\mathbf{g} / \mathbf{a v e} / \mathbf{d i a})\end{array}$ & $\begin{array}{c}\text { POST } \\
(\boldsymbol{\%})\end{array}$ & $\begin{array}{c}\text { OVI } \\
(\boldsymbol{\%})\end{array}$ & $\begin{array}{c}\text { PO } \\
(\mathbf{g})\end{array}$ & $\begin{array}{c}\text { MO } \\
\text { (g/ave/dia) }\end{array}$ & CA/dz & CA/kg \\
\hline $\mathbf{2 1}$ & 30,9 & 83,06 & 80,80 & 12,28 & 10,36 & 0,45 & 2,98 \\
$\mathbf{2 4}$ & 30,1 & 83,64 & 81,00 & 12,05 & 10,09 & 0,43 & 3,00 \\
$\mathbf{C V}(\boldsymbol{\%})$ & 4,54 & 4,10 & 4,88 & 2,45 & 4,47 & 5,62 & 6,01 \\
\hline $\mathbf{2 1}$ & $28,2 \mathrm{~A}$ & 81,47 & 76,12 & $12,02 \mathrm{~A}$ & $9,79 \mathrm{~A}$ & $0,42 \mathrm{~A}$ & 2,90 \\
$\mathbf{2 7}$ & $26,0 \mathrm{~B}$ & 80,71 & 75,54 & $11,41 \mathrm{~B}$ & $9,20 \mathrm{~B}$ & $0,39 \mathrm{~B}$ & 2,81 \\
$\mathbf{C V}(\boldsymbol{\%})$ & 4,11 & 4,06 & 5,20 & 1,93 & 3,95 & 5,84 & 5,12 \\
\hline $\mathbf{2 1}$ & $28,4 \mathrm{~A}$ & 79,96 & 75,56 & $12,14 \mathrm{~A}$ & $9,71 \mathrm{~A}$ & $0,43 \mathrm{~A}$ & $2,92 \mathrm{~A}$ \\
$\mathbf{3 0}$ & $25,0 \mathrm{~B}$ & 79,91 & 75,00 & $11,42 \mathrm{~B}$ & $9,12 \mathrm{~B}$ & $0,38 \mathrm{~B}$ & $2,74 \mathrm{~B}$ \\
$\mathbf{C V}(\boldsymbol{\%})$ & 4,48 & 4,85 & 5,21 & 1,40 & 4,36 & 5,70 & 5,92 \\
\hline $\mathbf{2 1}$ & $27,6 \mathrm{~A}$ & 80,76 & 74,97 & $12,03 \mathrm{~A}$ & $9,71 \mathrm{~A}$ & $0,41 \mathrm{~A}$ & 2,84 \\
$\mathbf{3 3}$ & $23,0 \mathrm{~B}$ & 77,25 & 71,21 & $11,19 \mathrm{~B}$ & $8,64 \mathrm{~B}$ & $0,36 \mathrm{~B}$ & 2,66 \\
$\mathbf{C V}(\boldsymbol{\%})$ & 8,52 & 5,17 & 7,05 & 2,93 & 5,42 & 9,37 & 9,09 \\
\hline $\mathbf{2 1}$ & $28,3 \mathrm{~A}$ & $79,04 \mathrm{~A}$ & $72,84 \mathrm{~A}$ & $12,32 \mathrm{~A}$ & $9,74 \mathrm{~A}$ & $0,43 \mathrm{~A}$ & 2,93 \\
$\mathbf{3 6}$ & $22,2 \mathrm{~B}$ & $73,77 \mathrm{~B}$ & $62,40 \mathrm{~B}$ & $10,85 \mathrm{~B}$ & $8,01 \mathrm{~B}$ & $0,36 \mathrm{~B}$ & 2,79 \\
$\mathbf{C V}(\boldsymbol{\%})$ & 6,96 & 5,28 & 7,03 & 2,51 & 6,53 & 8,60 & 9,29 \\
\hline
\end{tabular}

$A, B$ Médias seguidas de letras maiúsculas distintas, na coluna, dentro de cada ciclo de temperatura avaliada, diferem entre si, pelo teste de Tukey $(p \leq 0,05)$.

$\mathrm{Na}$ Tabela 2, constata-se que não houve efeitos significativos para nenhuma das variáveis avaliadas, dentro da comparação entre 21 e $24^{\circ} \mathrm{C}$. Estes resultados permitem afirmar que, mesmo encontrando-se fora da faixa ideal de temperatura para a fase de postura, que segundo Murakami \& Ariki (1998) situa-se entre 18 e $22^{\circ} \mathrm{C}$, as aves apresentaram bom desempenho.

Em relação ao consumo de ração, dentro da comparação entre a temperatura ambiente e a temperatura cíclica de $27^{\circ} \mathrm{C}$, pode-se observar redução de $7,8 \%$ para as 
aves submetidas ao estresse cíclico de $27^{\circ} \mathrm{C}$. Pode-se constatar ainda que, as aves expostas a este nível de estresse, apresentaram redução mais expressiva no consumo de ração $(7,8 \%)$ do que aquelas submetidas a estresse constante de $27^{\circ} \mathrm{C}(4,59 \%$, dados discutidos no capítulo anterior) o que resultou na piora de outras variáveis de desempenho como peso e massa de ovos, fato não observado no experimento anterior, no qual as aves foram expostas ao estresse constante. Todavia, observou-se apenas efeitos significativos na conversão alimentar por dúzia e quilograma de ovos produzidos tanto nas aves submetidas ao estresse contínuo e cíclico.

Dentro da comparação do consumo na temperatura termoneutra $\left(21^{\circ} \mathrm{C}\right) \mathrm{e}$ exposição das aves à temperatura cíclica de 30,33 e $36^{\circ} \mathrm{C}$, houve redução significativa de 11,$97 ; 16,67$ e $21,55 \%$, respectivamente. Temin et al (2000) também constataram redução no consumo de ração, com queda de $22 \%$, expondo frangos ao estresse contínuo de $35^{\circ} \mathrm{C}$, o que pode ser explicado pela dificuldade de dissipação do calor interno das aves sob alta temperatura ambiente (Yunis e Cahaner, 1999). Akşit et al. (2006) estudaram o efeito do estresse em frangos de corte da linhagem Ross, mantidos em três câmaras bioclimáticas com diferentes temperaturas durante 21 dias (temperatura controle de $22^{\circ} \mathrm{C}$; estresse cíclico a $28^{\circ} \mathrm{C}$ durante sete horas e 17 horas em temperatura controle- $22^{\circ} \mathrm{C}$ e estresse severo constante, $34^{\circ} \mathrm{C}$ ). Os autores constataram diferença significativa no consumo de ração apenas para as aves mantidas em estresse severo, com redução de $540 \mathrm{~g}$ no consumo de ração em comparação ao grupo controle. Contrariamente a estes dados, nesta pesquisa foi observado redução significativa no consumo de ração quando as aves foram expostas ao estresse cíclico de $27^{\circ} \mathrm{C}$.

Verificou-se redução numérica (4,34\%), porém não significativa na produção de ovos a $30^{\circ} \mathrm{C}$. Todavia, constatou-se redução significativa no percentual de postura, $6,67 \%$, apenas quando as aves estiveram sob efeito do estresse cíclico de $36^{\circ} \mathrm{C}$. Resultados semelhantes aos obtidos por Jones et al. (1976) utilizando poedeiras Leghorn brancas submetidas às temperaturas de $24,5^{\circ} \mathrm{C}$ e $35^{\circ} \mathrm{C}$, com rações de 2.671 , 2853 e $2992 \mathrm{kcal} \mathrm{EM} / \mathrm{kg}$, que concluíram que aves submetidas à temperatura constante de $35^{\circ} \mathrm{C}$ produziram, significativamente, menos ovos do que aquelas submetidas à temperatura de $24,5^{\circ} \mathrm{C}$. No experimento anterior, quando as aves foram submetidas em estresse contínuo houve redução significativa aos $30^{\circ} \mathrm{C}$, isto leva a crer que a magnitude, duração e o tipo de estresse a que as aves são submetidas é uma característica importante a ser considerada. 
Não houve diferença significativa para percentual de ovos viáveis nas comparações entre temperatura termoneutra, $24,27,30$ e $33^{\circ} \mathrm{C}$. No entanto, esta variável sofreu influência quando as aves foram expostas a estresse cíclico severo $\left(36^{\circ} \mathrm{C}\right)$ reduzindo, significativamente, o percentual de ovos viáveis em $14,33 \%$. No experimento referente ao capítulo anterior, resultados significativos foram encontrados quando as aves sofreram exposição às condições de estresse contínuo de $33^{\circ} \mathrm{C}$ reduzindo, significativamente, o percentual de ovos viáveis em $5,5 \%$; a elevação da temperatura para $36^{\circ} \mathrm{C}$ reduziu ainda mais o percentual de ovos viáveis para comercialização, $17,7 \%$. Os resultados obtidos com o percentual de ovos viáveis são decorrentes, provavelmente, da alteração nos níveis de cálcio plasmático disponíveis no organismo da ave que seriam destinados à formação da casca dos ovos. Esta alteração pode ser resultado do processo de alcalose respiratória que ocorre quando a ave encontra-se sob condições de estresse térmico.

No estresse por calor contínuo, a diminuição no consumo de ração é maior, já que as aves não podem compensar o consumo nas horas mais frescas da noite, como no estresse cíclico o que pode explicar a menor queda no consumo das aves e menor queda na produção de ovos no presente estudo.

Analisando-se os dados da Tabela 3, verifica-se queda significativa de 5,07\% no peso dos ovos quando a condição ambiental passou de conforto para o estresse cíclico de $27^{\circ} \mathrm{C}$. Quando as aves foram submetidas ao estresse cíclico de 30,33 e $36^{\circ} \mathrm{C}$ houve redução de 5,93\%; 6,98\% e $11,93 \%$ no peso dos ovos, respectivamente. Estes resultados podem ser decorrentes da elevada queda no consumo de ração quando as aves foram expostas a partir da temperatura de $27^{\circ} \mathrm{C}$, indisponibilizando os nutrientes essenciais para a produção e/ou desviando-os para manutenção da homeostasia. Bordas \& Minvelle (1997) também constataram efeitos negativos do estresse por calor em pesquisa realizada com galinhas poedeiras de diferentes linhagens. Ao submeter aves em ambientes com $21^{\circ} \mathrm{C}$ e $35^{\circ} \mathrm{C}$, observaram que houve uma redução de $13 \%$ no número de ovos e $4 \%$ no peso dos ovos, e que não houve diferenças no desempenho com relação à linhagem das aves.

A massa dos ovos (MO) foi significativamente menor a partir dos $27^{\circ} \mathrm{C}$, com redução de 6,37\% comparado à temperatura termoneutra. As aves apresentaram redução na massa dos ovos de 6,04; 10,93 e 17,78\% para as temperaturas cíclicas de 30 , 33 e $36^{\circ} \mathrm{C}$, respectivamente. Estas reduções ocorreram em função da menor percentagem de postura e peso dos ovos, observados nestas temperaturas. Por outro lado, Emery et al. (1984) estudando o efeito de temperaturas elevadas sobre o 
desempenho e a qualidade dos ovos de poedeiras, às 33 semanas de idade, em três câmaras bioclimáticas (uma câmara com temperatura constante de $23,9^{\circ} \mathrm{C}$; uma com temperatura cíclica entre 15,6 e $37,7^{\circ} \mathrm{C}$ e outra com temperatura cíclica entre 21,1 e $37,7^{\circ} \mathrm{C}$ ) relataram que não houve diferença estatística, dentro das três situações de estudo, para a produção de ovos, bem como para a massa de ovos.

Para a conversão alimentar por dúzia de ovos produzidos, observou-se melhores resultados a partir da exposição da temperatura cíclica de $27^{\circ} \mathrm{C}$, devido a uma grande redução no consumo de ração sem declínio proporcional da produção dos ovos. Em relação à conversão alimentar por quilograma de ração os resultados foram significativos somente quando as aves foram expostas à $30^{\circ} \mathrm{C}$, com melhoria de $6,16 \%$ na conversão alimentar comparado à temperatura termoneutra. Todavia, se o estresse pelo calor fosse prolongado por longos períodos de tempo, provavelmente as aves iriam necessitar de mobilização de reservas corporais para sua manutenção e, uma vez exauridas estas reservas, poderia haver redução na produção de ovos e piora nas demais características de desempenho. Akişit et al (2006) observaram que a conversão alimentar $(\mathrm{kg} / \mathrm{kg})$ foi significativamente afetada pelos tratamentos (estresse cíclico, $28^{\circ} \mathrm{C}$ durante sete horas e 17 horas em temperatura controle- $22^{\circ} \mathrm{C}$ e estresse severo constante, $34^{\circ} \mathrm{C}$ ) sendo maior para o grupo de estresse severo constante $\left(34^{\circ} \mathrm{C}\right)$ corroborando com os dados encontrados nesta pesquisa.

Plavnik \& Yahav (1998) estudaram os efeitos do estresse por calor em frangos de corte, de quatro a oito semanas de idade, mantidos em câmaras bioclimáticas, submetidos a três condições ambientais de estresse contínuo $\left(25,30\right.$ e $\left.35^{\circ} \mathrm{C}\right)$ e temperatura cíclica de $35^{\circ} \mathrm{C}$. Estes autores observaram redução progressiva do ganho de peso, no consumo de ração e na eficiência alimentar quando foram submetidos a aumentos de temperatura ambiental, principalmente quando expostas a altas temperaturas (estresse cíclico e severo de $35^{\circ} \mathrm{C}$ ) em relação aos valores observados a 25 e $30^{\circ} \mathrm{C}$. Resultados semelhantes aos encontrados nesta pesquisa.

Os dados referentes à qualidade dos ovos estão presentes na Tabela 3. Pode-se observar que os parâmetros estudados não foram afetados quando as aves foram submetidas a um estresse cíclico de temperatura. Contrariamente aos dados obtidos no experimento anterior, com aves expostas a estresse contínuo, no qual se observou maiores efeitos negativos do estresse térmico. 
Tabela 3. Gravidade específica (GE), resistência de casca à quebra (RES), espessura de casca (ESP), percentagem de casca (CASC), índice gema (IG), percentagem de gema (GEM), percentagem de albúmen (ALB) e unidade Haugh (UH) de ovos de codornas japonesas submetidas a estresse cíclico pelo calor.

\begin{tabular}{|c|c|c|c|c|c|c|c|c|}
\hline $\begin{array}{l}\text { Temp } \\
\left({ }^{\circ} \mathrm{C}\right)\end{array}$ & $\begin{array}{c}\mathbf{G E} \\
\left(\mathrm{mg} / \mathrm{cm}^{3}\right)\end{array}$ & $\begin{array}{c}\text { RES } \\
(\mathrm{g})\end{array}$ & $\begin{array}{c}\text { ESP } \\
(\mathbf{m m})\end{array}$ & $\begin{array}{c}\text { CASC } \\
(\%)\end{array}$ & IG & $\begin{array}{c}\text { GEM } \\
(\%)\end{array}$ & $\begin{array}{c}\text { ALB } \\
(\%)\end{array}$ & UH \\
\hline 21 & 1,072 & $962,71 \mathrm{~A}$ & 0,21 & 7,76 & 0,47 & 30,06 & 62,17 & 89,29 \\
\hline 24 & 1,072 & $869,28 \mathrm{~B}$ & 0,21 & 7,84 & 0,48 & 29,71 & 62,45 & 89,13 \\
\hline CV (\%) & 0,21 & 8,20 & 2,10 & 3,10 & 2,18 & 1,74 & 0,93 & 2,39 \\
\hline 21 & 1,073 & 886,41 & $0,21 \mathrm{~A}$ & 7,92 & 0,48 & 30,25 & 61,82 & 92,40 \\
\hline 27 & 1,073 & 873,37 & $0,20 \mathrm{~B}$ & 7,83 & 0,47 & 29,81 & 62,39 & 88,65 \\
\hline CV (\%) & 0,21 & 9,13 & 3,88 & 3,14 & 4,18 & 3,18 & 1,52 & 4,86 \\
\hline 21 & 1,075 & $961,06 \mathrm{~A}$ & 0,21 & 8,02 & 0,45 & 30,04 & $61,94 \mathrm{~A}$ & 85,09 \\
\hline 30 & 1,075 & $833,71 \mathrm{~B}$ & 0,21 & 7,82 & 0,45 & 29,09 & $63,24 \mathrm{~B}$ & 86,35 \\
\hline CV (\%) & 0,16 & 10,07 & 3,06 & 2,74 & 2,72 & 3,51 & 1,81 & 3,50 \\
\hline 21 & 1,073 & 942,49 & $0,21 \mathrm{~A}$ & 8,02 & 0,45 & 30,01 & 61,97 & 87,91 \\
\hline 33 & 1,073 & 966,64 & $0,20 \mathrm{~B}$ & 7,92 & 0,45 & 29,63 & 62,71 & 88,78 \\
\hline CV (\%) & 0,28 & 11,52 & 4,68 & 3,45 & 3,48 & 4,12 & 1,94 & 2,78 \\
\hline 21 & $1,073 \mathrm{~A}$ & 860,02 & 0,20 & 7,79 & 0,46 & 30,29 & 61,91 & 89,01 \\
\hline 36 & $1,070 \mathrm{~B}$ & 844,65 & 0,19 & 7,79 & 0,45 & 29,86 & 62,34 & 88,63 \\
\hline $\mathrm{CV}(\%)$ & 0,16 & 9,24 & 6,08 & 3,16 & 4,38 & 3,73 & 1,66 & 2,30 \\
\hline
\end{tabular}

A,B Médias seguidas de letras maiúsculas distintas, na coluna, dentro de cada ciclo de temperatura avaliada, diferem entre si, pelo teste de Tukey $(p<0,05)$.

Verifica-se que houve redução significativa para a gravidade específica apenas quando as aves foram submetidas ao estresse cíclico de $36^{\circ} \mathrm{C}$ em relação às condições de temperatura termoneutra. Segundo Hamilton (1982), a gravidade específica aumenta à medida que a espessura da casca aumenta, ou seja, os valores são diretamente relacionados.

Molino et al. (2009) afirmam que a melhor forma de analisar a qualidade da casca é a avaliação de sua resistência à quebra. Nesta pesquisa, a resistência da casca à quebra foi reduzida significativamente $(p<0,05)$ em $9,70 \%$, com o aumento da temperatura a $24^{\circ} \mathrm{C}$ em comparação à temperatura de $21^{\circ} \mathrm{C}$. Quando a temperatura foi elevada para $30^{\circ} \mathrm{C}$, a redução da resistência da casca à quebra foi de $13,25 \%$ comparado aos dados da temperatura termoneutra. A elevação da temperatura para 30 e $36^{\circ} \mathrm{C}$, comparado à temperatura termoneutra não obtiveram resultados significativos. 
Os resultados referentes à espessura de casca foram significativamente reduzidos para $4,37 \%$ quando as aves foram submetidas a estresse cíclico de $27^{\circ} \mathrm{C}$, comparado à temperatura ambiente. Quando submetidas aos $33^{\circ} \mathrm{C}$, houve redução de $4,33 \%$ na espessura da casca. A espessura da casca não obteve resultados significativos quando a temperatura foi elevada para 30 e $36^{\circ} \mathrm{C}$. Mashaly et al. (2004) submeteram aves poedeiras de 31 semanas a três tratamentos em câmara bioclimática, com temperaturas cíclicas e sob condições de estresse térmico constante de $35{ }^{\circ} \mathrm{C}$ e $50 \%$ de UR. Como resposta, os autores verificaram que o ganho de peso das aves e o consumo e ração foram significativamente reduzidos nas condições de estresse, bem como o peso dos ovos, espessura e peso da casca e a gravidade específica, resultados estes, semelhantes ao presente estudo.

A redução da qualidade interna do ovo diz respeito, principalmente, ao índice gema e a unidade Haugh. Para a condição ambiental de estresse térmico cíclico não se observou redução significativa para tais parâmetros. Estes dados reforçam o fato de que a duração, bem como a magnitude da exposição a temperaturas elevadas, são importantes características a serem consideradas.

Observando-se ainda a Tabela 3 , também constata-se que não foram encontrados resultados significativos para o percentual de gema e casca entre as temperaturas termoneutra e a temperatura teste, sendo observada redução significativa no percentual de albúmen quando as aves foram expostas a temperatura cíclica de $30^{\circ} \mathrm{C}$, com declínio de $2,10 \%$ quando comparada a condições de temperatura controle $\left(21^{\circ} \mathrm{C}\right)$.

$\mathrm{Na}$ Tabela 4 encontram-se os resultados de sólidos totais do albúmen e da gema de codornas submetidas a temperatura termoneutra e temperaturas de $24,27,30,33$ e $36^{\circ} \mathrm{C}$.

O conteúdo de sólidos totais no ovo inteiro é influenciado pela proporção de gema e albúmen e pelos seus conteúdos de sólidos. A proporção de gema e albúmen varia amplamente com o tamanho do ovo, assim, em ovos pequenos, há menor quantidade de gema que em ovos grandes. O albúmen é constituído principalmente de água (88\%), sendo sua quantidade de sólidos totais de $12 \%$. O conteúdo de sólidos totais da gema é de aproximadamente 50\% (Ahn et al., 1997; Tharrington et al., 1999; Scott \& Silversides, 2000). Não foram encontrados efeitos significativos de tratamento sobre a percentagem de sólidos totais de albúmen e de gema. 
Tabela 4. Percentagem de sólidos do albúmen e da gema para a temperatura termoneutra $\left(21^{\circ} \mathrm{C}\right)$ e para as temperaturas testes $(24,27,30,33 \mathrm{e}$ $\left.36^{\circ} \mathrm{C}\right)$.

\begin{tabular}{ccc}
\hline $\begin{array}{c}\text { Temp } \\
\left({ }^{\circ} \mathbf{C}\right)\end{array}$ & $\begin{array}{c}\text { Sólidos de Albúmen } \\
(\boldsymbol{\%})\end{array}$ & $\begin{array}{c}\text { Sólidos de Gema } \\
(\boldsymbol{\%})\end{array}$ \\
\hline $\mathbf{2 1}$ & 11,48 & 52,45 \\
$\mathbf{2 4}$ & 11,82 & 52,39 \\
$\mathbf{C V}(\boldsymbol{\%})$ & 3,4 & 3,24 \\
\hline $\mathbf{2 1}$ & 11,22 & 52,40 \\
$\mathbf{2 7}$ & 11,34 & 51,83 \\
$\mathbf{C V}(\boldsymbol{\%})$ & 3,02 & 2,54 \\
\hline $\mathbf{2 1}$ & 11,98 & 53,06 \\
$\mathbf{3 0}$ & 11,78 & 51,64 \\
$\mathbf{C V}(\boldsymbol{\%})$ & 3,98 & 2,90 \\
\hline $\mathbf{2 1}$ & 11,90 & 53,30 \\
$\mathbf{3 3}$ & 12,22 & 49,34 \\
$\mathbf{C V}(\boldsymbol{\%})$ & 3,67 & 3,59 \\
\hline $\mathbf{2 1}$ & 11,79 & 59,26 \\
$\mathbf{3 6}$ & 13,99 & 51,97 \\
$\mathbf{C V}(\boldsymbol{\%})$ & 4,07 & 3,19 \\
\hline
\end{tabular}

\section{CONCLUSÕES}

A partir de $27^{\circ} \mathrm{C}$ de exposição às condições de estudo, as aves já apresentaram evidências de estresse térmico com redução no consumo de ração, peso e massa dos ovos. A elevação cíclica de $36^{\circ} \mathrm{C}$ na temperatura ambiente afeta negativamente $\mathrm{o}$ percentual de ovos viáveis e o percentual de postura, comprovando o consequente efeito do estresse térmico no metabolismo e no equilíbrio térmico corporal das aves. Os efeitos das temperaturas cíclicas sobre a qualidade dos ovos não são conclusivos.

\section{REFERÊNCIAS}

Ahn, D.U.; Kim, S.M.; Shu, H. Effect of egg size and strain and age of hens on the solids content of chicken eggs. Poultry Science, 1997, 76: 914-919. 
Akşit, M.; Yalcın, S.; O"zkan, S.; Metin, K.; O"zdemir, D. Effects of temperature during rearing and crating on stress parameters and meat quality of broilers. Poultry Science, 2006, 85 (11): 1867-1874.

Baêta F. C. Acondicionamento térmico natural de galpões avícolas.In: SIMPÓSIO GOIANO DE AVICULTURA, 3, 1998, Goiânia. Anais... Goiânia: UFG, 1998: 29-34.

Bonnet, S.; Geraert, P.A.; Lessire, M.; Carre, B.; Guillumin, S. Effect of high ambient temperature on feed digestibility in broilers. Poultry Science, Champaign, 1997, 76 (6): 857-863.

Bordas, A.; Minvelle, F. Responsé à la chaleur de poules pondeuses issues de lignées sélectionnéss pour une faible $\left(R^{-}\right)$ou forte $\left(R^{+}\right)$consomation alimentaire résiduelle. Genetics, Selection, Evolution, 1997, 29 (3): 279-290.

Bottje, W. G.; Harrison, P. C. The effect of tap water, carbonated water, sodium bicarbonate, and calcium chloride on blood acid-base balance in cockerels subjected to heat stress. Poultry Science, 1985, 64 (1): 107-113.

Emery, D. A.; Vhora, R.; Ernst, R.A. The effect of cyclic and constant ambient temperatures on feed consumption, egg production, egg weight, and shell thickness of hens. Poultry Science, 1984, 63: 2027-2035.

Ferreira, D. F. Programa Sisvar.exe. Sistema de Análises de Variância. Versão 3.04, 1998.

Furlan, R. L.; Macari, M.; Moraes, V. M. B. et al. Alterações hematológicas e gasométricas em diferentes linhagens de frangos de corte submetidos ao estresse calórico agudo. Revista Brasileira de Ciência Avícola, 1999, 1 (1): 77-84.

Hamilton, R. M. G. Methods and factors that affect measurement of egg shell quality. Poultry Science, Champaign, 1982, 61: 2002-2039.

Hannas, M.I. Aspectos fisiológicos e a produção de suínos em clima quente. In: AMBIÊNCIA E QUALIDADE NA PRODUÇÃO INDUSTRIAL DE SUÍNOS, 1999, Piracicaba. Anais... Piracicaba: Fundação de Estudos Agrários Luiz de Queiroz, 1999: 01-33. 
Jones, J. E; Hughes, B. L.; Barnett, B. D. Effect of choching dietary energy levels and environmental temperatures on feed consumption and eggs production of sinle comb white Leghorns. Poultry Science, 1976, 55 (1): 274-277.

Macari, M.; Furlan, R.L.; Maiorka, A. Aspectos fisiológicos e de manejo para manutenção da homeostase térmica e controle de síndromes metabólicas. In: MENDES, A.A.; NÄÄS, I.A.; MACARI, M. (Eds.). Produção de frangos de corte. Campinas: Fundação Apinco de Ciência e Tecnologia Avícolas, 2004: 137-155.

Mashaly, M.M.; Hendrics, G.L.; Kalama, M.A. et al. Effect of heat stress on production parameters and imune response of comercial laying hens. Poultry Science, 2004, 83: 889-894.

Mazzuco, H. Bem-estar na avicultura de postura comercial: Sob a óptica científica. Avicultura industrial, 2006, 1, ano 97: 18-20.

Molino, A. B.; Garcia, E. A.; Gonçalves, H. C.; Pelícia, K.; Berto, D. A.; Silva, A. P. Avaliação de medidas de qualidade da casca dos ovos de poedeiras comerciais. In: VII CONGRESSO DE PRODUÇÃO, COMERCIALIZAÇÃO E CONSUMO DE OVOS, 2009, São Pedro, APA, 2009, Anais... p. 164-167.

Murakami, A. E.; Ariki, J. Produção de codornas japonesas. Jaboticabal: FUNEP, 1998. 79 p.

NRC - National Research Council. Nutrient requirements of poultry. Washington: Natl. Acad. Press. 9 ed., 1994; 156 p.

Plavnick, I.; Yahav, S. Effect of environmental temperature on broiler chickens subjected to growth restriction at an early age. Poult. Sci., Champaign, 1998, 77 (6): 870-872.

Scott, T.A.; Silversides, F.G. The effect of storage and strain of hen on egg quality. Poultry Science, 2000, 79: 1725- 1729. 
Silva, M.A.N.; Silva, I.J.O.; Piedade, S.M.S. et al. Resistência ao estresse calórico em frangos de corte de pescoço pelado. Revista Brasileira de Ciência Avícola, 2001, 3 (1): 27-33.

Silva, I.J.O. Qualidade do ambiente e instalações na produção industrial de suínos. In: SIMPÓSIO INTERNACIONAL DE SUINOCULTURA, 4., 1999, São Paulo. Anais... São Paulo: Gessuli, 1999: 108-121.

Staldeman, W. J.; Cotterill, O. J. Egg science and Technology. Food Products Prees,

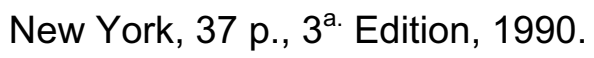

Tharrington, J. B.; Curtis, P. A.; Jones, F. T.; Anderson, K. E. Comparison of physical quality and composition of eggs from historic strains of single comb white leghorn chickens. Poultry Science, 1999, 78: 591-594.

Temin, S.; Chagneau, A.M.; Guillaumin, S. et al. Does excess dietary protein improve performance and carcass characteristics in heat-exposed chickens? Poultry Science, 2000, 79: 312-317.

Tinôco, I. F. F. Estresse calórico e meios naturais de condicionamento. SIMPÓSIO INTERNACIONAL SOBRE AMBIÊNCIA E INSTALAÇÃO NA AVICULTURA INDUSTRIAL, 1, 1995, Campinas. Anais... Campinas: Facta, 1995: 99-108.

Yahav, S.; Shinder, D.; Tanny, J. et al. Sensible heat loss: the broiler's paradox. World's Poultry Science Journal, 2005, 61 (3): 419-434.

Yunis, R.; Cahaner, A. The effects of naked neck (Na) and frizzle ( $F)$ genes on growth and meat yields of broilers and their interactions with ambient temperatures and potential growth rate. Poultry Science, 1999, 78: 1347-1352. 


\section{IMPLICAÇÕES}

Face às condições estruturais e conjunturais atuais da economia e da avicultura em particular, aspectos relacionados ao bem estar animal, até a pouco ignorados, passaram a ser relevantes, visto que viabilizam a expressão de fatores de produção complexos, primordiais à avicultura, à genética, à nutrição e à sanidade animal. Da mesma forma, possibilitam o alcance de novas metas ao aumento da quantidade e qualidade da produção a custos compatíveis.

Na maioria dos sistemas de produção de aves no Brasil os fatores climáticos são pouco gerenciados e o micro ambiente para a produção e bem-estar das aves nem sempre é compatível com as necessidades fisiológicas das mesmas.

Os resultados obtidos no presente trabalho indicam que aspectos como 0 ambiente e bem-estar devem ser considerados, pois podem afetar a qualidade do produto. Temperaturas acima de $27^{\circ} \mathrm{C}$ afetam a qualidade e a produção de ovos reforçando ser uma das causas da baixa eclosão e da malformação destes, com impacto imediato sobre a produtividade e a lucratividade. Contudo, estes dados permitem concluir que a temperatura crítica superior da zona de termoneutralidade para codornas japonesas é de $27^{\circ} \mathrm{C}$, a qual não deve ser excedida nas instalações de criação para evitar prejuízos no desempenho das aves e na qualidade dos ovos.

Os dados deste experimento permitem inferir ainda que, uma das principais diferenças entre temperaturas constantemente elevadas e estresse cíclico de temperatura é que, no segundo caso, as aves podem dissipar calor nos períodos de temperaturas mais amenas, opção não disponível às aves mantidas em altas temperaturas contínuas, na qual se observaram efeitos mais severos.

Portanto, com esta pesquisa foi possível constatar os efeitos deletérios de temperaturas elevadas sobre o desempenho e a qualidade dos ovos de codornas japonesas e, assim, outros trabalhos devem ser desenvolvidos para que se possam adotar medidas corretivas a fim de minimizar estes efeitos sobre a produção e ainda promover maior bem estar às aves. 